\title{
When Does the Family Govern the Family Firm?
}

\author{
Øyvind Bøhren, Bogdan Stacescu, Line F. Almli, \\ and Kathrine L. Søndergaard*
}

\begin{abstract}
We find that the controlling family holds both the chief executive officer and chair positions in $79 \%$ of Norwegian family firms. The family holds more governance positions when it owns large stakes in small, profitable, low-risk firms. This result suggests that the family trades off expected costs and benefits by conditioning participation intensity on observable firm characteristics. We find that the positive effect of performance on participation is twice as strong as the positive effect of participation on performance. The endogeneity of participation, therefore, should be carefully accounted for when analyzing the effect of family governance on the family firm's behavior.
\end{abstract}

\section{Introduction}

There is a large academic literature on whether the controlling family's participation in the family firm's governance matters for firm performance. O'Boyle, Pollack, and Rutherford (2012) list 78 such studies in 24 countries published in 1980-2008, while Amit and Villalonga (2014) list 45 studies in 20 countries published in 2003-2009. In contrast, much less attention has been paid to the closely related question of what induces the family to participate in the first place. We address this unexplored question by characterizing the settings where the family chooses to participate versus not participate in the family firm's governance, using proprietary data on about 70,000 private Norwegian family firms from 2000 to 2013.

The missing insight into the determinants of family participation can create serious identification problems in studies that examine the relationship between

\footnotetext{
*Bøhren (corresponding author), oyvind.bohren@bi.no, Stacescu, bogdan.stacescu@bi.no, BI Norwegian Business School; Almli, lalmli@deloitte.no, Søndergaard, ksondergaard@deloitte.no, Deloitte. We acknowledge valuable comments from Janis Berzins, Tom Colbjørnsen, Jeffrey Coles (the referee), Alex Edmans, Jarrad Harford (the editor), Rune J. Sørensen, Danielle Zhang, and seminar participants at BI, University of Edinburgh, University of Gothenburg, and the 2015 Workshop on Corporate Governance and Investment at the University of Manchester. We are very grateful to Janis Berzins for data on family size.
} 
participation and performance. The reason is that participation may not just drive performance but may also be driven by it if the family considers the firm's observed performance when making the participation decision. We use firm and family characteristics to disentangle the two-way causal relationship between participation and performance.

Our paper makes three contributions. The first is to distinguish between alternative participation intensities by analyzing when the family holds the chair position, the chief executive officer (CEO) position, both positions, or neither position. That is, we do not consider just participation as CEO, which is the position studied the most in the literature (Amit and Villalonga (2014)). Rather, by considering the two most influential governance positions, we analyze a wider menu of participation strategies from which the family can choose. We find that the typical controlling family participates very actively in governance, holding at least one of the two positions (CEO and chair) in $97 \%$ of the firms. However, there is large variation across participation types. For instance, the family holds both positions (high intensity) in $79 \%$ of the firms, only the CEO position (medium intensity) in $7 \%$, and only the chair position (low intensity) in $12 \%$.

Our second contribution is to show that the family's decision to participate in the family firm's governance depends on observable firm characteristics and that this relationship is consistent with the controlling family rationally trading off the costs and benefits of participation. Using ordered logit estimation, we find that the family participates more intensively the more equity it owns in the firm, the smaller the firm, the more profitable the firm, and the less risky the firm. This relationship holds in both single-owner and multiple-owner family firms, when we use alternative definitions of the family firm, and when we measure participation in alternative ways. We find no clear evidence that participation intensity follows a life cycle. Rather, participation stays fairly stable over the firm's life as long as the family remains in control.

We propose four economic rationales for this finding. First, the positive relationship between participation intensity and ownership supports the idea that a larger investment gives stronger incentives to be active in governance because more wealth is at stake. The relationship may also reflect that the controlling family tries to mitigate conflicts of interest with minority shareholders. A higher ownership percentage reduces the family's incentive to consume private benefits at minority shareholders' expense because more of the lost security benefit is internalized. Hence, intensive governance by the controlling family is less threatening to minority shareholders the more equity the family owns. This concern for shareholder conflicts is also supported by our finding that participation is less intensive in multiple-owner firms than in single-owner firms, where shareholder conflicts do not exist.

Second, our finding that the family is less active in larger firms supports the idea that governing larger firms requires skills that are harder to find inside the family than in the much greater pool of candidates outside the family. Thus, the family's desire to recruit the most talented officers and directors seems to be stronger than the temptation to use these positions to extract private benefits more easily. Third, the inverse relationship between participation and risk supports the notion that the family bears a cost for being undiversified. Taking employment 
at the same firm that produces most of the employee's wealth adds more to the costs of being undiversified the riskier the firm. Hence, higher risk in the family's financial investment induces the family to reduce the risk in its human capital investment.

Finally, the positive association between participation intensity and performance may reflect that the family tailors its participation to the firm's economic health. This result supports the idea that participation is not exogenous to the firm's prospects and that causation runs from performance to participation because the family uses past performance to self-select into governance.

The third contribution of our paper is to show that unless the self-selection into governance positions is accounted for, a regression of performance on participation will produce biased estimates of the coefficient for participation. This endogeneity of governance is a serious challenge for any study of how governance influences performance (Demsetz and Lehn (1985), Larcker and Rusticus (2007), Adams, Hermalin, and Weisbach (2010), Coles, Lemmon, and Meschke (2012), and Roberts and Whited (2013)). Nevertheless, the literature on family firm performance has mostly ignored this challenge. For instance, O'Boyle et al. (2012) conclude that the results across 78 studies of family firm performance are ambiguous, but they do not mention that this ambiguity may happen partially because the researchers ignore the endogeneity of family participation. ${ }^{1}$ While Amit and Villalonga (2014) do recognize the endogeneity problem, they point out that it is seldom addressed in the literature.

We address the endogeneity problem by analyzing whether causation runs from performance to participation, from participation to performance, or both ways. We use four approaches. First, we ensure participation is measured after its potential determinants in calendar time by using firm characteristics that are lagged rather than contemporary relative to participation. Second, we compare the relationship between participation and firm characteristics across new firms and mature firms, finding that the relationship is very similar. This property of new firms suggests that families choose to participate in firms with certain exogenous characteristics, rather than that these characteristics are caused by past participation.

Third, we conduct a Granger test, indicating that causality runs from ownership, performance, and size to participation intensity but not convincingly the opposite way. Finally, we regress performance on instrumented participation and regress participation on instrumented performance. Our instruments for performance are lagged growth in value added and employment in the county where the firm is headquartered. These local economic conditions matter for the firm's performance (relevance criterion) but should primarily influence participation indirectly through the firm's performance (exclusion criterion). We instrument for participation by the size of the controlling family, which is unlikely to affect the firm's performance except through family participation (exclusion). In contrast, we find that family size is positively correlated with the family's participation in

\footnotetext{
${ }^{1}$ For instance, the estimated relationship between family management and return on assets is positive in Luo and Chung (2005), negative in Bennedsen, Nielsen, Perez-Gonzalez, and Wolfenzon (2007), and zero in the meta-analysis of O'Boyle et al. (2012).
} 
governance (relevance). This relationship is as expected because a larger family provides more candidates for governance positions.

We find that causation runs both ways and that the positive effect from performance to participation is twice as large as the positive effect from participation to performance. A 1-standard-deviation increase in performance increases expected participation by more than one-third of its standard deviation, while a 1-standarddeviation increase in participation increases expected performance by less than one-fifth of its standard deviation. We also show that the widespread practice in the literature of ignoring the endogeneity of family participation produces biased estimates of how governance affects performance.

Four properties of our setting strengthen the external validity of our findings. First, our database includes every limited-liability firm in the Norwegian economy. Norwegian law mandates standardized accounting statements and certification by a public auditor, regardless of the firm's listing status, size, and industry. When combined with the family data, observing the population of firms allows us to accurately determine family firm status from any owner's ultimate (direct + indirect) equity stake. Compared to samples used in studies that ignore ownership (e.g., Bennedsen et al. (2007)) or consider just direct ownership in public firms (e.g., Villalonga and Amit (2006), Maury (2006)), our sample using ultimate ownership in private firms has wider, deeper, and more accurate data on firm and owner characteristics across a larger range of firms.

Second, most family firms in the world are private, and private firms constitute a much larger part of the economy than public firms do. For instance, 99.7\% of all Norwegian firms are private, and private firms are four times larger than public firms by aggregate sales, employment, and assets (Bøhren (2011)). Third, about $75 \%$ of all firms in the world are family firms (Nicholson (2008)). Thus, representative samples of family firms must include private firms. Nevertheless, 46 of the 78 studies on family firm performance surveyed by O'Boyle et al. (2012) consider only public firms. In contrast, the family firms we study are private, and family firms constitute $71 \%$ of all firms in the Norwegian economy. ${ }^{2}$

Finally, we define a family firm as one that is majority owned by individuals related by blood or marriage. This definition ensures that the choice of participation intensity is made by an entity that is coherent and tightly knit. Because majority ownership is sufficient to control the shareholder meeting and the board, our family firm definition also ensures that the family can decide whether to hold the chair and CEO positions without the other shareholders' consent. We prefer this definition to those in the literature, which use either lower control thresholds than $50 \%$, looser criteria for being a family than blood or marriage, or definitions using governance positions held rather than ownership (Anderson and Reeb (2003), Villalonga and Amit (2006), Maury (2006), and Bennedsen et al. (2007)). Also, definitions using governance positions held are not feasible in our setting, as

\footnotetext{
${ }^{2}$ Only three public firms in the population are majority owned by a family. Also, public firms, in general, have governance mechanisms that private firms lack. For instance, public firms have stronger regulation of insider trading, more liquid shares, closer analyst coverage, and requirements for board independence. Thus, including public family firms in our sample may mix apples and oranges regarding the governance effect of family participation. However, and maybe also because there are so few public firms, including public firms in our sample has no effect on the results.
} 
the very definition of a family firm, which determines the sample, would depend on what participation level the family chooses, which is the very decision we want to explain.

The external validity of our findings may be limited to countries with institutional structures and demographics that resemble those of the Norwegian setting, which is characterized by strong protection of investor rights and efficient legal enforcement (La Porta, Lopez-de-Silanes, Shleifer, and Vishny (2000), Spamann (2010)), and by citizens who are wealthy (International Monetary Fund (2018)) and well educated (OECD (2016)). In contrast, our results are rather insensitive to how we precisely measure participation or how we precisely define the family firm. Therefore, it may not be critical to have data sets as rich as ours when studying family firm performance in other countries. Nevertheless, rich data on family relationships may still be critical for constructing valid instruments for participation.

Overall, our evidence shows that family participation depends on firm and owner characteristics. This evidence supports the very limited literature that tries to account only for self-selection as CEO and that ignores ownership when defining the family firm. Bennedsen et al. (2007) use the gender of the first-born child to instrument for family participation in CEO successions. They find that secondgeneration participation is much more negative for performance than if the endogeneity of participation is ignored. Our findings confirm that participation may be the result of having a profitable firm to begin with rather than the opposite, implying that performance may drive participation even in first-generation firms. Villalonga and Amit (2006) estimate a selection model using idiosyncratic risk and lagged Tobin's q as instruments. We confirm that risk matters, but we also show that a wider set of family and firm characteristics is important when accounting for the family's self-selection into governance.

We present the theory in Section II, while we describe the data set and summary statistics in Section III. We show the statistical tests of our baseline model and the robustness tests in Section IV, and we examine the endogeneity of participation and performance in Section V. We conclude in Section VI.

\section{Theory}

In this section, we clarify what we mean by a family firm and by participation intensity (Section II.A), specify the costs and benefits of family participation in the family firm's governance (Section II.B), and state our hypotheses (Section II.C).

\section{A. Family Firm and Participation Intensity}

Unlike the existing literature, we define a family firm both by its particular governance and by its particular sociology. ${ }^{3}$ Regarding governance, control is

\footnotetext{
${ }^{3}$ While sociology concerns the relationship between individuals in general, the particular sociology of the family is due to emotional, expressive, and non-calculating relationships between the family members. The family is a primary example of what Tönnies (1887) called a Gemeinschaft (community), which is characterized by a deeper feeling of togetherness and mutual interest that the members want to maintain.
} 
the fundamental property (Tirole (2001)). Because shareholders elect the board, which hires and fires the CEO, owners with a majority stake at the shareholder meeting can control the chair and CEO positions. Therefore, we consider only firms where a group of owners hold more than half the voting rights. This group can single handedly choose its participation intensity. Regarding sociology, we consider only firms where the group of controlling owners consists of individuals who are a coherent entity tied together by blood or marriage up to the fourth degree of kinship. ${ }^{4}$

We prefer this definition to the numerous alternatives in the literature, which use either smaller ownership stakes, weaker family definitions, or the family's role in governance. In fact, O'Boyle et al. (2012) identify more than 30 definitions of a family firm in the literature on family firm performance. For instance, a family firm in Maury (2006) is a firm where the largest owner having at least $10 \%$ of the equity is either a true family, all personal shareholders as a group, or a private firm. This definition classifies too many firms as family firms from both a control perspective and a sociology perspective. Other definitions reflect only whether the family holds governance positions, regardless of ownership (Anderson and Reeb (2003), Villalonga and Amit (2006), and Bennedsen et al. (2007)). We think the important feature is whether the family has the option to take governance positions, not whether this option has been exercised. Hence, what matters is majority ownership. A firm that is majority owned by a family that has no CEO or board seats will not be a family firm under a definition using governance positions. Conversely, a firm where the family owns nothing, but holds a board seat, will be classified as a family firm. In contrast, our definition classifies the first firm as a family firm regardless of participation, but not the latter, despite participation. The definition we use may increase the power of our tests, because the definition requires unambiguous control of the CEO and chair positions by owning individuals who are closely related sociologically.

We use the term participation intensity to capture the controlling family's degree of involvement in the family firm's governance. Intensity is lowest under no participation, higher when the family holds only the chair position, even higher when the family holds only the CEO position, and highest when the family holds both positions.

\section{B. Costs and Benefits of Family Participation}

The hypotheses to be presented in Section II.C will rest on the simple idea that the controlling family chooses to participate with a certain intensity when this choice brings the family benefits that exceed costs. We consider three benefits of family participation in governance. The first benefit is reduced conflicts of interest between owners and managers. The resulting reduction of agency costs happens because there is less separation between principals and agents when the two roles merge (Jensen and Meckling (1976), Morck, Shleifer, and Vishny (1988)). This potential benefit is particularly large when the principal is a family, because an

\footnotetext{
${ }^{4}$ This definition means the family includes great-great-grandparents, great-aunts and great-uncles, aunts and uncles, cousins, grand-nieces, grand-nephews, parents, and siblings (https://www.mec.mo .gov/WebDocs/PDF/Misc/RelationshipChart.pdf).
} 
agent who is a family member may not have only economic incentives to govern well but may also be incentivized by loyalty to relatives.

The second benefit of participation is a stronger incentive to take a long-term perspective. This incentive may come from a feeling that identity and social prestige depend on the continued existence of the family firm as a legal entity. Hence, the family may consider participation a tool for ensuring the firm's survival. Such long-term thinking may increase the value of implicit contracts with other stakeholders (Sraer and Thesmar (2007)). The ability to build and maintain implicit contracts with employees may be particularly strong under family participation because active governance by the same family over extended periods may build social ties inside the firm. An important positive effect of this mutual trust is increased willingness by employees to invest in firm-specific human capital. Thus, family participation can be an antidote to managerial myopia, having a similar function as do long-term contracts for management (Bizjak, Brickley, and Coles (1993)) and antitakeover devices for the firm (Brickley, Coles, and Terry (1994)).

The third benefit of family participation in governance is less information asymmetry between the firm and its largest equity financier. The less informationally disadvantaged the financier, the less the firm must pay for financing (Leland and Pyle (1977)). This mechanism suggests that active governance by a controlling family may be an efficient way of reducing the value loss caused by asymmetric information.

The costs of family participation are due to undiversified wealth, shareholder conflicts, and low skills. Undiversified wealth stems from the family's high ownership stake. The wealth is already heavily dependent on a single source, which is the family firm's future cash flow. Taking employment in the firm increases the diversification loss even further. This increased loss happens because not just the family's wealth, but also its labor income is exposed to the family firm's idiosyncratic cash flow risk. Accordingly, the family may prefer to be intensively involved in governance only when the firm has low risk.

Shareholder conflicts happen when the controlling family makes decisions that benefit the family at the minority shareholders' expense. Such private benefits may materialize in several ways. Nepotism is one example, where the family uses its control to employ family members with lower skills than those of non-family candidates (Pollack (1985), Young, Peng, Ahlstrom, Bruton, and Jiang (2008)). The resulting cost of inferior competence is higher the larger the labor market outside the family firm because family firms in larger labor markets can recruit from a larger pool of managerial talent outside the family. Tunneling is another example of private benefits, where the family makes the firm trade at unfair prices with another firm where the family owns a higher equity percentage. As under nepotism, the family gains at the minority shareholders' expense (Johnson et al. (2000), Liu and Lu (2007)).

Nevertheless, private benefits obtained by expropriating minority shareholders may just be a first-stage effect. What looks like a benefit may eventually become a cost. First, the regulatory regime may punish majority shareholders who expropriate minority shareholders (La Porta, Lopez-de-Silanes, Shleifer, and Vishny (1998)). Second, the expropriation may increase the cost of raising new equity later because the family will have lost reputation as a co-investor 
(Gomes (2000), Berzins, Bøhren, and Stacescu (2018)). Hence, the family may initially be tempted to opportunistically reap private benefits but may ultimately lose if the family neglects disciplining mechanisms. Therefore, the net effect of private benefit consumption for the controlling family may be positive (i.e., a benefit) or negative (i.e., a cost). To simplify the exposition, we classify private benefits as a cost, recognizing that this cost may be positive or negative. ${ }^{5}$

Turning finally to low skills as the third cost of participation, the family's human capital is obviously limited. Therefore, the benefit of loyalty and aligned incentives for the family CEO may not be sufficient to offset the cost of insufficient skills. Such lack of competence may be particularly costly in environments that are unfamiliar to the family, where professional non-family chairs or managers may offer higher skills than family members possess.

\section{Hypotheses}

Using the arguments from Section II.B about the costs and benefits of family participation in the family firm's governance, we make six predictions about the relationship between participation intensity and firm characteristics.

Higher ownership increases the incentive and power to maximize value (Shleifer and Vishny (1986)). Hence, a higher percentage equity stake in the family firm, which is our proxy for ownership, gives the family stronger reasons to participate intensively. While increasing share value is the only relevant ownership argument for stronger participation in single-owner firms, the situation is less obvious in multiple-owner firms. As we discussed in Section II.B, the controlling family in multiple-owner firms may increase value for itself not just by increasing security benefits (i.e., value for all shareholders). The family may also increase value for itself by increasing private benefits (i.e., value for the family only). The more intensively the family participates, the easier the access to private benefits.

The argument against this expropriation strategy is that the incentive to capture private benefits is lower the higher the family's ownership stake. This reduced incentive is due to the fact that the more the controlling family owns, the more it must pay of what it costs to produce the private benefits. For instance, the family pays only $51 \%$ of the production costs for private benefits if the equity stake is $51 \%$, but $99 \%$ if the stake is $99 \%$. Hence, if the purpose of participation is to extract private benefits, participation intensity in multiple-owner family firms should decrease rather than increase as the family's ownership stake grows.

These two opposing effects mean that while the incentive to increase security benefits through intensive participation increases with ownership, the incentive to extract private benefits decreases. Moreover, and regardless of ownership, the incentive to extract private benefits is reduced by lost reputation and by legal protection against self-dealing, particularly under strong protection of minority shareholders, such as in Norway (La Porta et al. (2000), Spamann (2010)). Therefore,

\footnotetext{
${ }^{5}$ Certain non-pecuniary benefits for the controlling family may be positively correlated with firm performance and, hence, be in the interest of minority shareholders as well. For instance, a feeling of pride for the family firm's name may make the family spend more governance effort for less pecuniary pay than other owners would have spent. Because there is a gain for both the majority and the minority shareholders, this would not be an example of private benefits.
} 
somewhat arbitrarily, we predict that the net effect of these two opposing incentives will be a positive relationship between participation intensity and ownership:

Hypothesis 1 . The higher the equity percentage held by the controlling family, the stronger the tendency to participate.

For instance, a higher equity percentage induces the family to more often hold the CEO position or both the CEO and chair positions rather than just the chair or no position.

Performance may reflect the firm's robustness to tougher environments and weaker governance. Higher performance means higher margins and more slack, making the firm less sensitive to bad times in the future, including setbacks due to bad family governance. Accordingly, the required governance skills in the family may be lower the more profitable the firm. That is, because the required skills are lower because of high, exogenous (i.e., family-independent) performance, it is easier to find qualified candidates inside the family. We use the average return on assets over the past 3 years as a proxy for performance.

Hypothesis 2. There is a positive relationship between participation intensity and performance.

Hypothesis 2 follows regardless of whether causation runs from exogenous performance to endogenous participation (as argued previously) or from exogenous participation to endogenous performance (as argued by most of the literature on family firm performance). We distinguish empirically between these two alternative rationales for Hypothesis 2 in Section $\mathrm{V}$.

Just like performance, the size of the firm may reflect the skills needed to govern it successfully. Specifically, larger firms may be more complex and thus may require better talent. Therefore, finding sufficient skills inside the family may be harder the larger the firm. Also, because larger firms also tend to be more transparent, the information asymmetry argument for using family participation to reduce the cost of capital is weaker the larger the firm. We measure firm size as inflation-adjusted sales.

Hypothesis 3. There is a negative relationship between participation intensity and firm size. ${ }^{6}$

Naveen (2006) finds that internal CEO succession in public firms is more common the larger the firm. Using size as a measure of firm complexity and a resulting need for deep CEO insight, Naveen argues that compared to external CEOs, internal CEOs produce less costly succession the larger the firm. Hypothesis 3 argues, however, that the family takes governance positions less often the larger the firm. This hypothesis may still be consistent with Naveen's arguments. First, while the pool of non-family candidates inside the firm increases as the family firm grows, the pool of family candidates does not. Second, as the firm grows

\footnotetext{
${ }^{6}$ This prediction ignores that the incentive to extract private benefits may increase with firm size. Greater firm size may increase the family's private benefits from holding governance positions because larger firms may allow for better social visibility (Jensen and Meckling (1976)). This agency-related argument suggests a positive relationship between firm size and participation. For the sake of simplicity, we specify only the talent-related hypothesis, bearing in mind that the agency logic makes the opposite prediction.
} 
and becomes more complex, it is less likely that the family will have the best candidate. Thus, while larger firm size increases the value of internal CEOs and the pool of such candidates, the likelihood of finding a family member in this pool may decrease.

The firm's age may reflect complexity and, hence, the skills required to govern the firm successfully (Berry, Bizjak, Lemmon, and Naveen (2006)). Age may also correlate with maturity in a governance sense because older firms may more often have professionalized their governance functions by using a non-family CEO and chair (Sraer and Thesmar (2007)). Older firms are also generally more transparent than younger firms.

Hypothesis 4. There is a negative relationship between participation intensity and firm age.

As we discussed in Section II.A, the family becomes more exposed to risk if family members take employment in the firm. Risky firms may also be harder to govern because they face a more unpredictable environment. Hence, both the skills argument and the diversification argument suggest that participation falls as risk declines.

Hypothesis 5. There is a negative relationship between participation intensity and risk.

We measure risk by the coefficient of variation for sales over the previous 3 years.

Participation may also depend on the market for governance talent. Family firms may find less non-family talent and fewer outside options for the family's talent the harder it is to find employment outside the family firm. Therefore, the opportunity cost of hiring less-qualified candidates from the family may be lower and the family's benefits may be higher the smaller the local labor market.

Hypothesis 6. There is a negative relationship between participation intensity and the size of the outside pool for governance talent.

We consider the outside talent pool large if the firm is located in Norway's top five cities, and small otherwise ("rural").

Summarizing, we hypothesize that the controlling family's participation intensity in the family firm's governance relates positively to the family's equity stake and to the firm's performance. The participation intensity relates negatively to the firm's size, age, and risk, and to the size of the local market for governance talent.

\section{Data and Summary Statistics}

Norway has Scandinavian-type civil law, which is considered less protective of ownership rights than is common law. Nevertheless, La Porta et al. (1998) find that Norway's legal regime provides greater shareholder protection than does the legal regime of the average common law country. Norwegian private firms have single-tier boards and are not exposed to a regulatory minimum for board independence. Each director needs half the shareholder votes to be elected, there is no cumulative voting, and the CEO is hired and fired by the board. 
Our proprietary data set covers every private Norwegian family firm having limited liability from 2000 to 2013 . $^{7}$ Starting from the population of all family firms, we exclude financials and utilities to avoid the impact of atypical capital requirements, ownership restrictions, and accounting rules. To avoid non-operating firms, we require positive sales, assets, and employment. We include the parent and exclude the subsidiaries because the parent is usually the critical governance entity in a group.

Our regressions use the firm's average performance and average risk over the past 3 years. Accordingly, a sample firm must have at least 4 consecutive years of data. The resulting pooled sample has about 410,000 firm years, 70,000 unique firms, and 29,000 firms per year. Column 2 in Panel A of Table 1 shows the fraction of firms controlled by a family across nine major industries.

The average percentage of family firms in the economy is $71 \%$, varying between a maximum of $75 \%$ in construction and a minimum of $56 \%$ in publishing,

\section{TABLE 1}

Prevalence of Family Firms and the Controlling Family's Participation Intensity across Industries and Years

Panel A of Table 1 shows the frequency of family firms in the economy by industry and the average intensity of the controlling family's governance activity in the firm. Panel B shows the frequency by which the controlling family participates in the family firm's governance as specified in the first column. A family is a group of owning individuals in the firm who are related by blood or marriage up to the fourth degree of kinship. A family firm is a firm in which the ultimate equity share of the largest family by ownership exceeds 50\%. As specified in Panel B, participation intensity equals 3 if the family has both the CEO and the chair, 2 if the family has only the CEO, 1 if the family has only the chair, and 0 if the family holds neither position. The sample consists of all private Norwegian family firms with limited liability from 2000 to 2013. We exclude financials, utilities, and subsidiaries, and we require positive assets, sales, and employment.

Panel A. Family Firms by Industry

\begin{tabular}{|c|c|c|c|}
\hline Industry & $\begin{array}{l}\text { Ratio of } \\
\text { Family Firms } \\
\text { to All Firms }\end{array}$ & $\begin{array}{l}\text { Controlling Family's } \\
\text { Participation Intensity } \\
\text { in Family Firms }\end{array}$ & $N$ \\
\hline Construction & $75 \%$ & 2.69 & 89,652 \\
\hline Agriculture, forestry, fishing & $74 \%$ & 2.60 & 8,087 \\
\hline Retail, wholesale & $73 \%$ & 2.64 & 180,332 \\
\hline Transport, tourism & $71 \%$ & 2.59 & 48,115 \\
\hline Services & $69 \%$ & 2.63 & 134,716 \\
\hline Light industry & $68 \%$ & 2.60 & 27,748 \\
\hline Real estate & $68 \%$ & 2.49 & 19,730 \\
\hline Mining, oil, heavy industry & $65 \%$ & 2.59 & 30,966 \\
\hline Publishing, media, IT & $56 \%$ & 2.58 & 29,438 \\
\hline All & $71 \%$ & 2.63 & 568,784 \\
\hline
\end{tabular}

Panel B. Participation Intensity by Year

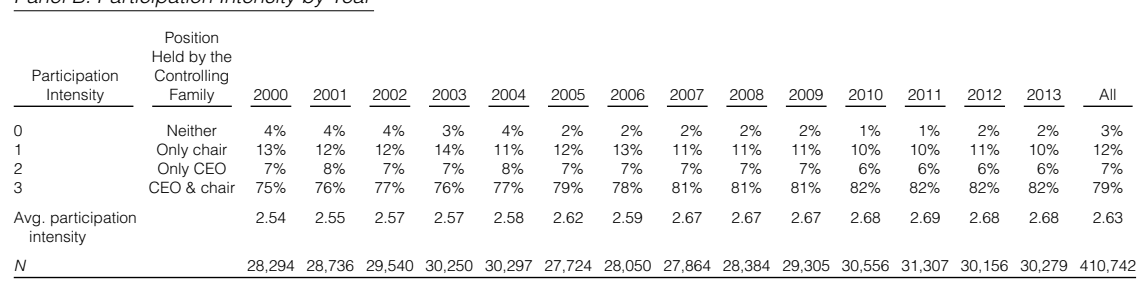

\footnotetext{
${ }^{7}$ Accounting and governance data are delivered by Experian (www.experian.com). Data on family relationships are from Skattedirektoratet (www.skatteetaten.no/en/person/). The data were received electronically and organized as one integrated database by the Centre for Corporate Governance Research (www.bi.edu/ccgr). The data set includes every ultimate equity stake by every shareholder in every firm. The family data include relationships by blood or marriage up to the fourth level of kinship between every pair of owners, directors, and CEOs.
} 
media, and information technology (IT). Thus, the family firm is the predominant organizational form and the family's tendency to hold a controlling stake varies considerably across industries. These facts suggest it is important to understand the governance of family firms and that industry characteristics may be an exogenous determinant of the decision to establish a family firm in the first place.

The third column in Table 1 shows that the family's average participation intensity varies across industries, being highest in construction $(2.69$ on a scale from 0 to 3 ) and lowest in real estate (2.49). Industries with a higher percentage of family firms tend to have controlling families with more intensive participation, the correlation coefficient being 0.45 (not reported in the table). Thus, industry characteristics seem to matter both for the tendency to establish a family firm and for the family's choice of participation intensity in the firm's governance. We address only the second issue, not trying to explain the decision to establish the family firm in the first place. Therefore, we take the family firm as given, control for its industry, and try to explain how the controlling family participates in the firm's governance.

Panel B of Table 1 details the controlling family's participation intensity year by year and in the pooled sample. The figures show that participation is extremely common, that average participation intensity is high, and that the aggregate tendency to participate is stable over time. Specifically, the family participates in one way or another in $97 \%$ of the cases and the average participation intensity is 2.63 . Holding both governance positions happens in $79 \%$ of the cases, reflecting that the most common choice is maximum intensity. Holding just one position occurs in $19 \%$ of the cases, consisting of $12 \%$ where the family has only the chair position and $7 \%$ where the family has only the CEO position. Hence, not participating at all $(3 \%)$ and holding only the CEO position (7\%) are the least-common outcomes of the participation decision.

We show summary statistics for the potential determinants of family participation in Table 2. Because Panel A documents that the mean values are quite stable over time, we focus on the pooled sample in Panel B. ${ }^{8}$ Although the controlling family's equity stake varies between $50.1 \%$ and $100 \%$, the median firm has no minority shareholders because the firm is fully owned by one family. The family's mean OWNERSHIP stake is $92.7 \%$, implying that the average family controls every decision at the shareholder meeting, including the right to freeze out the minority, which requires a $90 \%$ stake. Because the average controlling family pays $92.7 \%$ of any private benefit directly, the incentive to capture private benefits is generally low.

PERFORMANCE (real return on assets (ROA)) is $3.4 \%$ on average and varies much more across the firms than does ownership. As expected, performance was atypically low during the financial crisis in 2008-2010. ${ }^{9}$ The average firm's SIZE, as measured by sales, is 8 million NOK (about 0.8 million euros), varying between 0.001 million and 202 billion. Thus, many family firms are small, but

\footnotetext{
${ }^{8}$ The only exception is a slightly increasing trend for the controlling family to have a greater equity stake. Average age also increases slightly, which is because our sampling filter requires at least 4 years of consecutive data.

${ }^{9}$ To capture a firm's typical profitability, we use average returns on assets over the previous 3 years in the regressions. Using lagged or contemporaneous returns does not qualitatively change our results.
} 


\section{TABLE 2}

Descriptive Statistics for Potential Determinants of the Controlling Family's Participation Intensity

Table 2 shows descriptive statistics for potential determinants of the controlling family's participation in the family firm's governance. OWNERSHIP is the ultimate equity fraction held by the firm's largest family by ownership. PERFORMANCE is operating earnings after taxes divided by total assets averaged over the past 3 years, while SIZE is real sales in millions of NOK as of year-end 2013. PERFORMANCE and SIZE are both winsorized at the $1 \%$ and $99 \%$ tails. AGE is the number of years since the firm was founded, while RISK is the standard deviation of sales divided by the absolute value of sales over the past 3 years. RURAL is a dummy variable that is 1 if and only if the family firm is located outside Norway's five largest cities. The sample consists of all private Norwegian family firms with limited liability. We exclude financials, utilities, and subsidiaries, and we require positive assets, sales, and employment. A family firm is a firm in which the ultimate equity share of the largest family by ownership exceeds $50 \%$. A family is a group of owning individuals in the firm who are related by blood or marriage up to the fourth degree of kinship.

Panel A. Mean Values Year by Year

\begin{tabular}{|c|c|c|c|c|c|c|c|c|c|c|c|c|c|c|c|}
\hline ant & 000 & 2001 & 2002 & 003 & 004 & 005 & 006 & 2007 & 2008 & 009 & 010 & 11 & 012 & 13 & All \\
\hline & & & & 0.912 & & & & & & D & & & & & 092 \\
\hline & & & & & & & & & & & & & & & \\
\hline & & & & & & & & & & & & & & & \\
\hline & 12 & 11.642 & 11.657 & 1 & 50 & 9 & 3.695 & 8 & 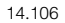 & 6 & & & & & 3.5 \\
\hline & & & & & & & & & & & & & & & \\
\hline 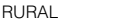 & & 636 & 0.0 & .005 & 0.606 & 608 & 609 & 0.0 & 0.6 & 0.6 & & & 0.022 & 0.616 & 0.01 \\
\hline v & 3,924 & 28,736 & 29,539 & 0,250 & 0,297 & 27,724 & 27,807 & 27,864 & 28,384 & 29,305 & 30,556 & 31,307 & 30,154 & 0,2 & 0, \\
\hline
\end{tabular}

Panel B. Distributional Properties across All Years

\begin{tabular}{|c|c|c|c|c|c|c|c|}
\hline Determinant & Mean & $\begin{array}{l}\text { Standard } \\
\text { Deviation }\end{array}$ & Median & Minimum & Maximum & Skewness & Kurtosis \\
\hline OWNERSHIP & 0.927 & 0.142 & 1.000 & 0.501 & 1.000 & -1.716 & 1.387 \\
\hline PERFORMANCE & 0.034 & 0.269 & 0.058 & -1.838 & 0.689 & -2.623 & 12.249 \\
\hline SIZE & 7.940 & 201.718 & 3.388 & 0.001 & 201.718 & 17.533 & 38.767 \\
\hline AGE & 13.598 & 10.625 & 11.000 & 1.000 & 168.000 & 3.054 & 23.954 \\
\hline RISK & 0.257 & 0.505 & 0.140 & 0.001 & 134.310 & 130.958 & $30,177.980$ \\
\hline RURAL & 0.616 & 0.486 & 1.000 & 0.000 & 1.000 & -0.477 & -1.773 \\
\hline
\end{tabular}

some are huge. The AGE variable shows that the average firm was founded about 14 years ago, while the oldest firm was founded 168 years ago. The RISK measure, calculated as the coefficient of variation for sales, shows that the standard deviation of sales in the average firm is one-fourth of the mean. ${ }^{10}$

We relate the four alternative participation intensities to the mean and the median of each determinant in Table 3. Panel A shows the raw values, while Panel B shows the difference in means. Given the large sample size, we discuss only relationships with $p$-values of $1 \%$ or less.

Comparing first non-participation (intensity 0 ) to participation of any kind (intensities 1-3) in Panel A of Table 3, participating families have, on average, higher OWNERSHIP than non-participating families do regardless of how participation happens. For instance, the average equity stake is $94.5 \%$ when the family holds both the CEO and chair positions (3) but only $79.9 \%$ when the family holds no governance position (0). Participation is also more common the higher the PERFORMANCE of the firm. For instance, average ROA is 3.8\% versus $-0.2 \%$ at intensity level 3 versus 0 , respectively. Notice also that compared to the minimum participation intensity, maximum intensity involves higher average OWNERSHIP and PERFORMANCE, while average SIZE is smaller and AGE and RISK are lower. Firms with maximum participation intensity are also more often located in rural areas (RURAL).

\footnotetext{
${ }^{10}$ Due to the relatively high kurtosis of size, age, and risk, we log transform these variables in the regressions. We also winsorize performance and size at the $1 \%$ and $99 \%$ tails.
} 
TABLE 3

Family Firm Governance by Potential Determinants

Table 3 relates the controlling family's participation intensity in the family firm's governance to the mean and median (in italics below the mean) values of potential determinants. The participation types are specified in the first column, while the determinants are in columns 2-7. OWNERSHIP is the ultimate equity fraction held by the firm's largest family by ownership. PERFORMANCE is operating earnings after taxes divided by total assets averaged over the past 3 years, while SIZE is real sales in millions of NOK as of year-end 2013. PERFORMANCE and SIZE are both winsorized at the $1 \%$ and $99 \%$ tails. AGE is the number of years since the firm was founded, while RISK is the standard deviation of sales divided by the absolute value of sales over the past 3 years. RURAL is a dummy variable that is 1 if and only if the family firm is located outside Norway's five largest cities. The sample consists of all private Norwegian family firms with limited liability in 2000-2013. We exclude financials, utilities, and subsidiaries, and we require positive assets, sales, and employment. A family firm is a firm in which the ultimate equity share of the largest family by ownership exceeds $50 \%$. A family is a group of owning individuals in the firm who are related by blood or marriage up to the fourth degree of kinship. In Panel $B,{ }^{\star}$ and ${ }^{* *}$ indicate $t$-values statistically different from 0 at the $5 \%$ and $1 \%$ levels, respectively.

$\underline{\text { Panel A. Mean and Median Values }}$

\begin{tabular}{|c|c|c|c|c|c|c|c|}
\hline \multirow{2}{*}{$\begin{array}{l}\text { Governance } \\
\text { Position } \\
\text { Held by the } \\
\text { Controlling } \\
\text { Family } \\
\end{array}$} & \multicolumn{7}{|c|}{ Determinant } \\
\hline & OWNERSHIP & PERFORMANCE & SIZE & $\underline{A G E}$ & $\underline{\text { RISK }}$ & RURAL & $N$ \\
\hline 0 Neither & $\begin{array}{l}0.799 \\
0.800\end{array}$ & $\begin{array}{r}-0.002 \\
0.041\end{array}$ & $\begin{array}{r}11.607 \\
4.696\end{array}$ & $\begin{array}{l}13.926 \\
11.000\end{array}$ & $\begin{array}{l}0.268 \\
0.143\end{array}$ & $\begin{array}{l}0.599 \\
1.000\end{array}$ & 10,286 \\
\hline 1 Only chair & $\begin{array}{l}0.900 \\
1.000\end{array}$ & $\begin{array}{l}0.024 \\
0.054\end{array}$ & $\begin{array}{l}7.982 \\
3.172\end{array}$ & $\begin{array}{l}13.251 \\
11.000\end{array}$ & $\begin{array}{l}0.287 \\
0.147\end{array}$ & $\begin{array}{l}0.584 \\
1.000\end{array}$ & 47,366 \\
\hline 2 Only CEO & $\begin{array}{l}0.816 \\
1.000\end{array}$ & $\begin{array}{l}0.029 \\
0.052\end{array}$ & $\begin{array}{r}13.139 \\
5.959\end{array}$ & $\begin{array}{l}13.447 \\
11.000\end{array}$ & $\begin{array}{l}0.235 \\
0.138\end{array}$ & $\begin{array}{l}0.641 \\
1.000\end{array}$ & 27,948 \\
\hline 3 CEO \& chair & $\begin{array}{l}0.945 \\
1.000\end{array}$ & $\begin{array}{l}0.038 \\
0.059\end{array}$ & $\begin{array}{l}7.370 \\
3.234\end{array}$ & $\begin{array}{l}13.652 \\
11.000\end{array}$ & $\begin{array}{l}0.254 \\
0.139\end{array}$ & $\begin{array}{l}0.619 \\
1.000\end{array}$ & 324,894 \\
\hline
\end{tabular}

Panel B. Difference in Mean Values

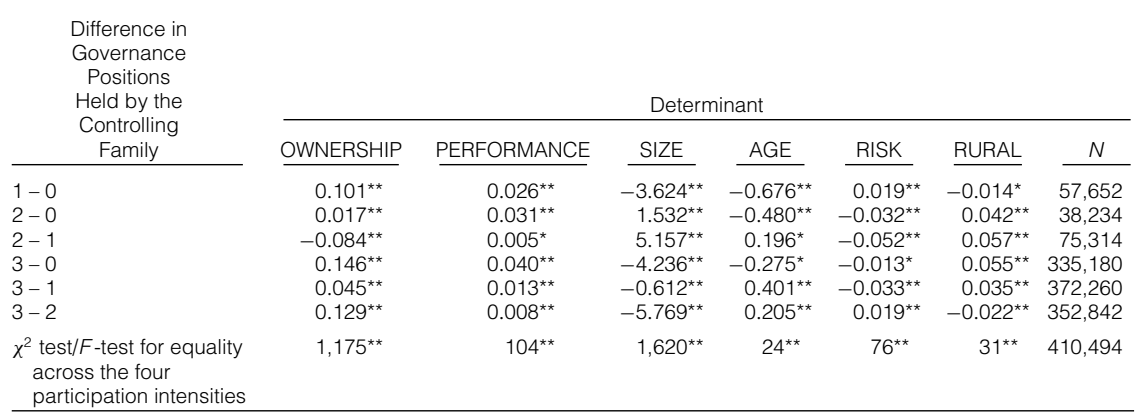

Panel B of Table 3 compares the mean value of the determinants from Panel A across pairs of participation intensities. Consider first the situation in the bottom three rows of the table, where the family holds both governance positions. In that situation, the average majority stake is the largest (94.5\%), profitability the largest (3.8\%), and size the smallest (7.4 million NOK). Holding just the CEO position rather than just the chair is more common when the family owns less $(81.6 \%$ vs. $90.0 \%$ ) and when the firm is more profitable (2.9\% vs. $2.4 \%)$, larger (13.1 million NOK vs. 8.0 million NOK), older (13.4 years vs. 13.3 years), less risky (relative volatility of 0.24 vs. 0.29$)$, and not rural ( $62 \%$ vs. $64 \%$ of the cases). The last line in the panel presents test statistics for comparisons across all four groups. The estimates support the idea that every characteristic is significantly different for firms with different degrees of family participation. ${ }^{11}$

\footnotetext{
${ }^{11}$ Inspired by Panel A of Table 1, we have also run $\chi^{2}$ tests for participation intensity across industries, finding significant differences. We, therefore, include industry dummies in all our regressions.
} 
Appendix Table A1 investigates the relationship between participation and firm size further by splitting the sample into firm-size deciles. The table shows that as firm size increases, the controlling family gradually participates less in governance. When participation happens, larger firm size makes the family hold both the CEO and chair positions less often and only the CEO position more often. This pattern is more distinct when the family is not the only shareholder (multipleowner firm). That is, firm size matters less for participation intensity when there is no minority shareholder (single-owner firm).

Appendix Table A2 shows bivariate correlation coefficients in the pooled sample and in the final sample year (2013). Consistent with the approach we will be using in the regressions, we lag OWNERSHIP and SIZE by 1 year, while PERFORMANCE and RISK in year $t$ are measured over the years $t-1$ to $t-3$. The table shows that there are no multicollinearity problems in the data.

The summary statistics in this section have shown that family firms with more intensive governance participation by the controlling family differ from other family firms. Moreover, certain firm characteristics are more typical for one participation intensity than for another. Consistent with the hypotheses in Section II, the univariate relationships suggest that participation intensity relates positively to ownership and performance and negatively to size and risk. This evidence suggests that the choice of participation intensity relates endogenously to firm characteristics that may already have been in place when the family took its governance roles. Section IV analyzes this idea more rigorously by relating the family's participation intensity to its potential determinants in a multivariate framework.

\section{Statistical Tests of the Baseline Model}

Using the hypotheses from Section II, we specify and estimate our baseline model in Section IV.A. Robustness tests follow in Section IV.B.

\section{A. The Baseline Model}

The dependent variable is the controlling family's choice of participation intensity in the family firm. This choice involves four alternative participation intensities that are mutually exclusive and collectively exhaustive. We formalize this setting by an ordered logit model, where the dependent variable PARTICIPATION $_{i t}$ can take on four different values for firm $i$ at time $t$. A higher value reflects higher intensity, as explained in Section II.A. Our baseline model is

(1) PARTICIPATION $_{i t}=\beta_{0}+\beta_{1}$ OWNERSHIP $_{i t}+\beta_{2}$ PERFORMANCE $_{i t}$ $+\beta_{3} \mathrm{SIZE}_{i t}+\beta_{4} \mathrm{AGE}_{i t}+\beta_{5} \mathrm{RISK}_{i t}+\beta_{6} \mathrm{RURAL}_{i t}+\varepsilon_{i t}$.

OWNERSHIP is the controlling family's ultimate equity percentage, PERFORMANCE is the average real ROA from $t-3$ to $t-1$, SIZE is the natural $\log$ of real sales in millions of NOK, AGE is the natural log of the number of years since the firm was founded, RISK is the natural log of the coefficient of variation for sales from $t-3$ to $t-1$, and RURAL is a dummy variable that is 1 if and only if the family firm is located outside Norway's five largest cities. 
We lag OWNERSHIP and SIZE by 1 year, while PERFORMANCE and RISK are automatically lagged by their definition. The larger the absolute value of a coefficient, the stronger the economic relationship between the firm characteristic and the likelihood of intensive participation.

We estimate the model in equation (1) year by year and in the pooled sample. Given the findings in Table 1, all regressions account for the firm's industry. The pooled regressions use year dummies to account for the time trends indicated by Table 2, and we cluster standard errors at the firm level to account for correlated observations. We also estimate the pooled model using random firm effects to account for omitted firm characteristics. ${ }^{12}$ Table 4 reports the estimates.

The first noticeable result is that nearly every relationship is stable. This property emerges as typical in subsequent regressions, too. Therefore, we will mostly use the estimates from the pooled sample, while trying not to make inferences that are invalid year by year.

The second noticeable property in Table 4 is that the multivariate results reproduce many relationships revealed by the univariate analysis in Table 3 . Once more we find that family firms with active family involvement differ from other family firms along several dimensions. Family firms with more intensive family

\section{TABLE 4}

Estimates of the Baseline Model

Table 4 reports the estimates of the model in equation (1) of the main text using an ordered logit approach. The dependent variable PARTICIPATION can take on four different values: 3 if the family has both the CEO and the chair, 2 if the family has only the CEO, 1 if the family has only the chair, and 0 if the family holds neither position. OWNERSHIP is the lagged ultimate equity fraction held by the firm's largest family by ownership. PERFORMANCE is operating earnings after taxes divided by total assets in real terms averaged over the past 3 years, while SIZE is the lagged natural log of real sales in millions of NOK as of year-end 2013. PERFORMANCE and SIZE are both winsorized at the $1 \%$ and $99 \%$ tails. AGE is the natural log of the number of years since the firm was founded, while RISK is the natural log of the ratio between the standard deviation of sales and the mean sales over the previous 3 years. RURAL is a dummy variable that is 1 if and only if the family firm is located outside Norway's five largest cities. The sample consists of all private Norwegian family firms with limited liability. We exclude financials, utilities, and subsidiaries, and we require positive assets, sales, and employment. A family firm is a firm in which the ultimate equity share of the largest family by ownership exceeds $50 \%$. A family is a group of owning individuals in the firm who are related by blood or marriage up to the fourth degree of kinship. The pooled sample used in the two rightmost columns covers the period 2001-2013. All regressions include industry dummies. The pooled panel regression uses year dummies and standard errors clustered at the firm level. The random firm effects panel regression uses year dummies and robust standard errors. The standard error is reported in italics below the estimated coefficient. ${ }^{*},{ }^{* *}$, and ${ }^{* \star *}$ indicate coefficients with $t$-values statistically different from 0 at the $10 \%, 5 \%$, and $1 \%$ levels, respectively.

\begin{tabular}{|c|c|c|c|c|c|c|c|c|c|c|c|c|c|c|c|}
\hline \multirow[b]{2}{*}{$\begin{array}{l}\text { Independent } \\
\text { Variable }\end{array}$} & \multicolumn{15}{|c|}{ Dependent Variable: PARTICIPATION } \\
\hline & 2001 & 2002 & 2003 & 004 & 05 & 06 & 2007 & 2008 & 2009 & 010 & 011 & 2012 & 2013 & $\begin{array}{c}\text { Pooled } \\
\text { Panel } \\
\end{array}$ & 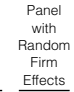 \\
\hline OWNERSHIP & $\begin{array}{l}0.019^{* \star \star x} \\
0.001\end{array}$ & $\begin{array}{l}0.023^{\star * \star} \\
0.001\end{array}$ & $\begin{array}{l}0.024^{\star \star \star *} \\
0.001\end{array}$ & $\begin{array}{l}0.025^{\star * \star \star} \\
0.001\end{array}$ & $\begin{array}{l}0.027^{\star \star \star \star} \\
0.001\end{array}$ & $\begin{array}{l}0.026^{* \star *} \\
0.001\end{array}$ & $\begin{array}{l}0.028^{* \star \star} \\
0.001\end{array}$ & $\begin{array}{l}0.028^{* \star \star *} \\
0.001\end{array}$ & $\begin{array}{l}0.034^{\star \star \star \star} \\
0.001\end{array}$ & $\begin{array}{l}* 0.033^{\star \star \star} \\
0.001\end{array}$ & $\begin{array}{l}* 0.036^{\star \star \star *} \\
0.001\end{array}$ & & & $\begin{array}{l}0.028^{* * *} \\
0.001\end{array}$ & $\begin{array}{l}0.035^{* * *} \\
0.001\end{array}$ \\
\hline PERFORMANCE & $\begin{array}{l}0.610^{* * *} \\
0.001\end{array}$ & $\begin{array}{l}0.520^{\star \star \star *} \\
0.090\end{array}$ & $\begin{array}{l}0.450^{\star \star * *} \\
0.078\end{array}$ & $\begin{array}{l}* 0.512^{\star * \star} \\
0.074\end{array}$ & $\begin{array}{ll}* & 0.520^{* * *} \\
& 0.072\end{array}$ & $\begin{array}{ll}* & 0.603^{\star \star \star \star} \\
0.073\end{array}$ & $\begin{array}{l}0.489^{* * *} \\
0.083\end{array}$ & $\begin{array}{l}0.455^{* \star *} \\
0.083\end{array}$ & $\begin{array}{l}0.396^{\star \star \star *} \\
0.079\end{array}$ & $\begin{array}{ll}* & 0.310^{\star \star * \star} \\
0.079\end{array}$ & $\begin{array}{ll}* & 0.273^{* * *} \\
0.074\end{array}$ & & & $\begin{array}{l}0.466^{\star \star * x} \\
0.037\end{array}$ & $\begin{array}{ll} & 0.392^{\star * \star} \\
& 0.062\end{array}$ \\
\hline SIZE & $\begin{array}{l}-0.135^{* \star *} \\
0.001\end{array}$ & $\begin{array}{l}-0.149^{* \star *} \\
0.012\end{array}$ & $\begin{array}{l}-0.149^{* \star *} \\
0.011\end{array}$ & $\begin{array}{c}-0.169^{* * \star} \\
0.012\end{array}$ & $\begin{array}{c}* 0.096^{* \star \star} \\
0.013\end{array}$ & $\begin{array}{c}-0.063^{\star \star \star *} \\
0.012\end{array}$ & $\begin{array}{l}-0.1223^{\star \star \star} \\
0.013\end{array}$ & $\begin{array}{l}-0.098^{* * *} \\
0.013\end{array}$ & $\begin{array}{l}-0.088^{\star \star \star x} \\
0.013\end{array}$ & $\begin{array}{c}* 0.114^{\star * \star} \\
0.013\end{array}$ & $\begin{array}{c}* \\
=0.111^{\star \star \star *} \\
0.012\end{array}$ & $\begin{array}{c}* 0.118^{\star * \star *} \\
0.013\end{array}$ & $\begin{array}{c}-0.104^{* * x} \\
0.012\end{array}$ & $\begin{aligned} & -0.120^{* * *} \\
& 0.008\end{aligned}$ & $\begin{array}{c}-0.116^{* \star \star \star} \\
0.013\end{array}$ \\
\hline AGE & $\begin{array}{l}0.028 \\
0.023\end{array}$ & $\begin{array}{l}0.014 \\
0.024\end{array}$ & $\begin{array}{l}0.038^{* *} \\
0.022\end{array}$ & $\begin{array}{r}-0.032 \\
0.022\end{array}$ & $\begin{array}{r}-0.003 \\
0.023\end{array}$ & $\begin{array}{r}-0.015 \\
0.023\end{array}$ & $\begin{array}{r}-0.031 \\
0.024\end{array}$ & $\begin{array}{l}-0.064^{* * *} \\
0.023\end{array}$ & $\begin{array}{c}-0.042^{\star} \\
0.023\end{array}$ & $\begin{array}{c}-0.053^{\star *} \\
0.023\end{array}$ & $\begin{array}{c}-0.069^{* * x} \\
0.022\end{array}$ & $\begin{array}{c}* 0.066^{* \star \star} \\
0.023\end{array}$ & $\begin{array}{c}-0.054^{* *} \\
0.023\end{array}$ & $\begin{array}{c}-0.028^{* *} \\
0.013\end{array}$ & $\begin{array}{c}-0.114^{* * \star} \\
0.023\end{array}$ \\
\hline RISK & $\begin{array}{c}-0.036^{* \star} \\
0.016\end{array}$ & $\begin{array}{c}-0.033^{\star *} \\
0.015\end{array}$ & $\begin{array}{l}-0.049^{* \star *} \\
0.014\end{array}$ & $\begin{array}{c}* 0.041^{* \star *} \\
0.015\end{array}$ & $\begin{array}{c}* 0.046^{* \star \star} \\
0.016\end{array}$ & $\begin{array}{c}-0.059^{\star \star \star *} \\
0.016\end{array}$ & $\begin{array}{l}-0.088^{* \star *} \\
0.016\end{array}$ & $\begin{array}{l}-0.074^{* \star \star} \\
0.017\end{array}$ & $\begin{array}{l}-0.075^{\star \star \star} \\
0.017\end{array}$ & $\begin{array}{c}-0.047^{\star \star \star} \\
0.017\end{array}$ & $\begin{array}{c}* 0.098^{* \star *} \\
0.016\end{array}$ & $\begin{array}{c}* 0.101^{\star \star \star \star} \\
0.016\end{array}$ & $\begin{aligned} * & -0.079^{* * *} \\
& 0.016\end{aligned}$ & $\begin{array}{l}-0.059^{\star * * *} \\
0.007\end{array}$ & $\begin{array}{rl}-0.041^{* \star \star *} & 0.010\end{array}$ \\
\hline RURAL & $\begin{array}{r}-0.015 \\
0.032\end{array}$ & $\begin{array}{l}0.016 \\
0.031\end{array}$ & $\begin{array}{l}0.023 \\
0.029\end{array}$ & $\begin{array}{r}-0.011 \\
0.030\end{array}$ & $\begin{array}{l}0.020 \\
0.032\end{array}$ & $\begin{array}{l}0.005 \\
0.032\end{array}$ & $\begin{array}{l}0.019 \\
0.033\end{array}$ & $\begin{array}{l}0.005 \\
0.033\end{array}$ & $\begin{array}{r}-0.025 \\
0.033\end{array}$ & $\begin{array}{l}0.012 \\
0.033\end{array}$ & $\begin{array}{l}0.017 \\
0.032\end{array}$ & $\begin{array}{l}0.042 \\
0.033\end{array}$ & $\begin{array}{l}0.059^{*} \\
0.033\end{array}$ & $\begin{array}{l}0.010 \\
0.021\end{array}$ & $\begin{array}{l}0.134 \\
0.036\end{array}$ \\
\hline $\begin{array}{l}\text { Pseudo- } R^{2} \\
N\end{array}$ & $\begin{array}{r}0.022 \\
23,857\end{array}$ & $\begin{array}{r}0.027 \\
26,109\end{array}$ & $\begin{array}{r}0.030 \\
29,586 \\
\end{array}$ & $\begin{array}{r}0.031 \\
29,686 \\
\end{array}$ & $\begin{array}{r}0.033 \\
27,164 \\
\end{array}$ & $\begin{array}{r}0.033 \\
27,253 \\
\end{array}$ & $\begin{array}{r}0.039 \\
26,706 \\
\end{array}$ & $\begin{array}{r}0.043 \\
27,699 \\
\end{array}$ & $\begin{array}{r}0.046 \\
28,606 \\
\end{array}$ & $\begin{array}{r}0.049 \\
28,606 \\
\end{array}$ & $\begin{array}{r}0.053 \\
30,615 \\
\end{array}$ & $\begin{array}{r}0.050 \\
29,371 \\
\end{array}$ & $\begin{array}{r}0.048 \\
29,555 \\
\end{array}$ & $\begin{array}{r}0.039 \\
364,916 \\
\end{array}$ & $\begin{array}{r}0.088 \\
364,916 \\
\end{array}$ \\
\hline
\end{tabular}

\footnotetext{
${ }^{12}$ We cannot use fixed-effects estimation, which produces biased estimates in ordered logit specifications (Greene and Hensher (2008)).
} 
governance tend to have a higher ownership stake by the family, to perform better, to be smaller, and to be less risky. This evidence supports Hypothesis 1 (OWNERSHIP), Hypothesis 2 (PERFORMANCE), Hypothesis 3 (SIZE), and Hypothesis 5 (RISK). Age and location seldom matter, providing little support for Hypothesis 4 (AGE) and Hypothesis 6 (RURAL). Moreover, PERFORMANCE and SIZE are the firm characteristics having the largest odds ratios and, hence, the strongest economic significance. The random effects model suggests a modest life-cycle effect. Finally, the estimates are quite similar across the two models with panel data that do (random firm effects) and do not (pooled) account for unobserved firm characteristics. Hence, it seems that ignoring unobservables in the participation regression will not produce serious bias.

The overall impression from testing the baseline model in equation (1) is that family governance of family firms is not random relative to major firm characteristics. Controlling families in certain family firms tend to stay away from governance, whereas controlling families in other family firms tend to participate intensively. In particular, and as predicted, family participation is more intensive the larger the family's ownership percentage, the higher the firm's performance, the smaller the firm's size, and the lower the firm's risk.

\section{B. Robustness}

This section explores the sensitivity of the baseline results to excluding firms where controlling shareholders cannot reap private benefits (Section IV.B.1), to using alternative definitions of a family firm (Section IV.B.2), to using alternative measures of participation (Section IV.B.3), and to distinguishing between new and mature family firms (Section IV.B.4).

\section{Private Benefits}

The baseline sample includes every family firm in the Norwegian economy, regardless of whether the controlling family owns the firm alone or with minority shareholders. If participation in governance depends on the incentive to capture private benefits, however, such an incentive is irrelevant in single-owner firms. Table 5 estimates the baseline model using alternatively the sample of all family firms (i.e., the baseline sample from Table 4), of multiple-owner family firms, and of single-owner family firms.

The estimates are very consistent across the three samples except for AGE and RURAL. Therefore, the relationships we found in Table 4 between PARTICIPATION and OWNERSHIP, PERFORMANCE, SIZE, and RISK are independent of whether the controlling family owns the firm alone or with others. This finding supports the argument that the consumption of private benefits is not an important incentive for the family's participation in the firm's governance.

\section{Defining the Family Firm}

The baseline model defines the family firm according to the majority control of individuals related by blood or marriage. Appendix Table A3 maintains the sociological dimension of the family firm in definitions 1-5 but uses four alternative control thresholds to the $50 \%$ threshold used so far. Definitions 1 (largest family holds $>10 \%$ ) and 2 (largest family holds $>20 \%$ ) are common in studies of public firms (Villalonga and Amit (2006)), definition 3 (largest family holds $>1 / 3$ ) 
TABLE 5

Minority Shareholders and the Controlling Family's Participation Intensity

Table 5 estimates the baseline model in equation (1) for family firms with versus without minority shareholders. We use an ordered logit model where the dependent variable PARTICIPATION can take on four different values: 3 if the family has both the CEO and the chair, 2 if the family has only the CEO, 1 if the family has only the chair, and 0 if the family holds neither position. OWNERSHIP is the lagged ultimate equity fraction held by the firm's largest family by ownership. PERFORMANCE is operating earnings after taxes divided by total assets in real terms averaged over the past 3 years, while SIZE is the lagged natural log of real sales in millions of NOK as of year-end 2013. PERFORMANCE and SIZE are both winsorized at the $1 \%$ and $99 \%$ tails. AGE is the natural log of the number of years since the firm was founded, while RISK is the natural log of the ratio between the standard deviation of sales and the mean sales over the previous 3 years. RURAL is a dummy variable that is 1 if and only if the family firm is located outside Norway's five largest cities. The sample consists of all private Norwegian family firms with limited liability over the period 2001-2013. We exclude financials, utilities, and subsidiaries, and we require positive assets, sales, and employment. A family is a group of owning individuals in the firm who are related by blood or marriage up to the fourth degree of kinship. A family firm is a firm in which the ultimate equity share of the largest family by ownership exceeds $50 \%$. The regressions include industry and year dummies. Standard errors are clustered at the firm level and reported in italics below the estimated coefficient. * and ${ }^{* *}$ indicate coefficients with $t$-values statistically different from 0 at the $5 \%$ and $1 \%$ levels, respectively. NA indicates not applicable.

Dependent Variable: PARTICIPATION

\begin{tabular}{|c|c|c|c|}
\hline \multirow[b]{2}{*}{ Independent Variable } & \multicolumn{3}{|c|}{ Sample: Family Firms } \\
\hline & All & Multiple-Owner & $\underline{\text { Single-Owner }}$ \\
\hline OWNERSHIP & $\begin{array}{l}0.028^{\star *} \\
0.001\end{array}$ & $\begin{array}{l}0.021^{\star *} \\
0.001\end{array}$ & $\begin{array}{l}\text { NA } \\
\text { NA }\end{array}$ \\
\hline PERFORMANCE & $\begin{array}{l}0.466^{\star *} \\
0.037\end{array}$ & $\begin{array}{l}0.558^{\star *} \\
0.057\end{array}$ & $\begin{array}{l}0.376^{\star \star} \\
0.047\end{array}$ \\
\hline SIZE & $\begin{array}{c}-0.120^{\star *} \\
0.008\end{array}$ & $\begin{array}{c}-0.197^{\star *} \\
0.012\end{array}$ & $\begin{array}{c}-0.063^{\star \star} \\
0.010\end{array}$ \\
\hline AGE & $\begin{array}{c}-0.028^{*} \\
0.013\end{array}$ & $\begin{array}{l}0.081^{\star *} \\
0.021\end{array}$ & $\begin{array}{c}-0.063^{\star \star} \\
0.017\end{array}$ \\
\hline RISK & $\begin{array}{c}-0.059^{* *} \\
0.007\end{array}$ & $\begin{array}{c}-0.047^{\star *} \\
0.011\end{array}$ & $\begin{array}{c}-0.059^{\star \star} \\
0.010\end{array}$ \\
\hline RURAL & $\begin{array}{l}0.010 \\
0.021\end{array}$ & $\begin{array}{c}-0.097^{\star \star} \\
0.031\end{array}$ & $\begin{array}{l}0.083^{\star \star} \\
0.028\end{array}$ \\
\hline $\begin{array}{l}\text { Pseudo- } R^{2} \\
N\end{array}$ & $\begin{array}{r}0.039 \\
364,916\end{array}$ & $\begin{array}{r}0.023 \\
100,958\end{array}$ & $\begin{array}{r}0.008 \\
263,636\end{array}$ \\
\hline
\end{tabular}

ensures the family is protected against unwanted charter amendments, definition 4 is our baseline definition from Table 4, while definition 5 (largest family holds $>2 / 3$ ) ensures that the family can amend the charter without needing support from minority shareholders.

The estimated values of the significant coefficients are consistent across the five control thresholds except for AGE. Hence, the 50\% ownership threshold for family control is not what drives our baseline results. ${ }^{13}$

Unlike family firm definitions $1-5$, definitions 6 and 7 do not use family relationships to select the sample. This may be the only available option when comprehensive family data are missing (Maury (2006)). Moreover, unlike definitions 1-5, definitions 6 and 7 use only direct holdings rather than the sum of direct and indirect holdings to measure ownership. Nevertheless, the significant coefficients

\footnotetext{
${ }^{13}$ The two major independent variables, SIZE and PERFORMANCE, can be measured in different ways. First, firm size can be measured by the book value of assets rather than by sales, as we do in the baseline model. Assets may possibly pick up more than differences in scale, such as technology and capital intensity. Second, performance can be measured by the book return on equity rather than by the book return on assets, as we do in the baseline model. Whereas asset returns reflect valuation effects for all financiers as a group, equity returns reflect effects only for shareholders. Unreported results show that the estimates are practically identical regardless of whether we measure size by assets or sales and regardless of whether we measure performance by return on equity or on assets.
} 
in 6 and 7 are consistent with those in 1-5, showing once more that our baseline results are robust to whether the largest owner is a majority shareholder.

In all seven regressions, we measure participation in governance using the largest family by ownership, regardless of how the sample of family firms is defined. Thus, the more important result in this robustness test is that the participation decision of the firm's largest family by ownership depends on the same firm characteristics regardless of how we define the family firm. To analyze this participation decision, however, the researcher needs comprehensive data on family relationships between the firm's owners, managers, and chairs regardless of whether those data are used to select the sample of family firms.

\section{Alternative Participation Measures}

The ordered logit model used so far estimates the coefficients for the determinants of participation in a single regression that captures four different participation intensities. An alternative approach is to use a series of binomial logit models, where each model captures just two of the participation intensities from the ordered logit. The dependent variable equals 1 if the observation reflects participation of the specified type, and 0 otherwise. Models 1-3 in Appendix Table A4 show the estimates from three such models. The results are consistent with those of the ordered logit in Table 4. In particular, governance activity of greater intensity is associated with higher OWNERSHIP and PERFORMANCE, with smaller SIZE, and with lower RISK. Also, the family more often holds both the CEO and chair positions rather than just the CEO position when the firm is located in a rural area. This latter relationship is not visible in Table 4.

Model 4 of Appendix Table A4 considers all cases of a family CEO, regardless of whether the family also holds the chair. This is the most common case in the literature. The estimates show that having a family CEO is less common the larger the family firm. This result supports our argument from Section II that although the pool of non-family CEO candidates inside the firm increases as the firm grows, the pool of family candidates does not grow. We also argue that finding the best candidate in the family is less likely when the firm becomes larger and more complex. Thus, our result that having a family CEO is less common the larger the firm does not contradict Naveen (2006), who finds that internal CEO succession in public firms is more common in larger firms, not considering whether the internal candidate belongs to the family.

CEO-chair duality occurs when the same person holds both the CEO and chair positions. This duality may matter for the board's role as a monitor (Brickley, Coles, and Jarrell (1997)). Model 5 considers this situation at the controlling family level, that is, when the two governance positions are held not just by the controlling family but by the same family member. The estimates are consistent with those of the baseline model. The estimates are also consistent for models 6 and 7, where we measure participation as a board consisting exclusively of family members and as the percentage of seats held by the family, respectively.

\section{Firm Age}

The results so far show that the firm's age often relates only weakly to the largest family's participation in governance. This finding suggests that family 
participation is stable over time. Because some of our explanatory variables require information from several past years, however, our sample did not include very young firms.

Comparing new firms to mature firms allows us to check whether family participation is set for many years from the moment the firm is born. More importantly, this comparison allows us to learn more about endogeneity through selfselection. In particular, if certain firm characteristics exist in firms with strong family participation from the very beginning of the firm's life, it would be strong evidence that exogenous firm characteristics matter when the family decides how intensively to become involved in governance. That is, causation would run from firm characteristics to family participation, which we will analyze in detail in Section V.

We single out newly established family firms in Panel A of Table 6 and check whether they differ from the average family firm regarding participation intensity. We measure participation in the new firm in its second year of existence and ensure the firm is active by requiring positive assets, sales, and employment that year. ${ }^{14}$ The estimates show that participation intensity in new firms is quite independent of the year the firm is founded. The intensity is also strikingly similar to what it is in the average family firm regardless of age. For instance, average PARTICIPATION for all firms is 2.63 in Table 1 and 2.65 in the subsample of new firms in Table 6 . Hence, the family's tendency to use non-family governance resources is not much different in newly established firms than in other firms.

These results give little support to an idea of a governance life cycle, where the family's participation changes as the firm matures and the value of active ownership changes. This idea is inspired by the general insight that because optimal governance is context dependent, one size will not fit all (Coles, Daniel, and Naveen (2008)). Panel B of Table 6, which considers family firms that are at least 30 years old in any year (old firms), confirms the impression that there is no distinct life cycle in the data. In fact, the results are very similar to those in Panel A of Table 6. For instance, average PARTICIPATION is 2.65 in both new and old firms. The regression results in Panel C tell the same story. In particular, it is true for both young and old firms that more intensive participation is associated with higher OWNERSHIP for the controlling family, higher PERFORMANCE, and smaller SIZE. ${ }^{15}$ Thus, there is no clear life cycle in the controlling owner's governance effort.

Overall, this section has shown that the firm's largest family by ownership participates more intensively in governance the larger the family's ownership percentage, the higher the firm's performance, the smaller the firm's size, and the lower the firm's risk. These relationships are insensitive to how we define the family firm, to how we measure participation intensity, and to whether the family firm is new or mature.

\footnotetext{
${ }^{14}$ We choose the second year of existence to avoid firms that do not report their accounting statements until the year after incorporation.

${ }^{15}$ Because new firms have no history, we measure the firm's risk as the average risk in the firm's industry.
} 
TABLE 6

Firm Age and the Dynamics of Participation Intensity

Table 6 relates family participation to the firm's age. Panels A and B show the frequency by which the controlling family participates in the governance of new and old family firms. Panel A analyzes firms in their second year of existence, while the firms in Panel B are 30 years or older. PARTICIPATION is 3 if the family has both the CEO and the chair, 2 if the family has only the CEO, 1 if the family has only the chair, and 0 if the family holds neither position. A family is a group of owning individuals in the firm who are related by blood or marriage up to the fourth degree of kinship. A family firm is a firm in which the ultimate equity share of the largest family by ownership exceeds $50 \%$. Panel $C$ reports the estimates of the model in equation (1) using ordered logit on firms of age 2 years (new firms) or at least 30 years (old firms). OWNERSHIP is the lagged ultimate equity fraction held by the firm's largest family by ownership. PERFORMANCE is operating earnings after taxes divided by total assets in real terms averaged over the past 3 years, while SIZE is the lagged natural log of real sales in millions of NOK as of year-end 2013. PERFORMANCE and SIZE are both winsorized at the $1 \%$ and $99 \%$ tails. RISK is the natural log of the ratio between the standard deviation of sales and the mean sales over the previous 3 years. RURAL is a dummy variable that is 1 if and only if the family firm is located outside Norway's five largest cities. The sample consists of all private Norwegian family firms with limited liability over the period 2001-2013. We exclude financials, utilities, and subsidiaries, and we require positive assets, sales, and employment. The regressions include time dummies and industry dummies. We use standard errors clustered at the firm level, which are reported in italics below the estimated coefficient. ${ }^{*},{ }^{* \star}$, and ${ }^{* \star *}$ indicate coefficients with $t$-values statistically different from 0 at the $10 \%, 5 \%$, and $1 \%$ levels, respectively.

Panel A. New Firms

Governance

Position Held by the

Controlling Family

0 Neither

1 Only chair

2 Only CEO

3 CEO \& chair

Avg. participation

intensity

N

Year Founded

\begin{tabular}{|c|c|c|c|c|c|c|c|c|c|c|c|c|c|c|}
\hline 000 & 2001 & 2002 & 2003 & 2004 & 2005 & 2006 & 2007 & 2008 & 2009 & 2010 & 2011 & 2012 & 2013 & All \\
\hline $3 \%$ & $4 \%$ & 3 & $2 \%$ & $4 \%$ & & $3 \%$ & $2 \%$ & 1 & $2 \%$ & $2 \%$ & & & $\%$ & $2 \%$ \\
\hline $10 \%$ & $13 \%$ & $10 \%$ & $14 \%$ & $10 \%$ & $12 \%$ & $12 \%$ & $9 \%$ & 11 & $8 \%$ & $9 \%$ & $9 \%$ & $10 \%$ & 10 & $11 \%$ \\
\hline $7 \%$ & $8 \%$ & $10^{\circ}$ & $9 \%$ & $9 \%$ & $7 \%$ & $8 \%$ & $6 \%$ & $7 \%$ & $6 \%$ & $6 \%$ & 0 & $6 \%$ & $5 \%$ & $7 \%$ \\
\hline $80 \%$ & $75 \%$ & $77 \%$ & $75 \%$ & $77 \%$ & $78 \%$ & $77 \%$ & $83 \%$ & $80 \%$ & $84 \%$ & $82 \%$ & $84 \%$ & $82 \%$ & $83 \%$ & $80 \%$ \\
\hline 2.63 & 2.54 & 2.62 & 2.57 & 2.59 & 2.61 & 2.59 & 2.71 & 2.67 & 2.71 & 2.70 & 2.72 & 2.68 & 2.71 & 2.65 \\
\hline 8 & 73 & ,747 & 2,079 & 2,200 & 1,995 & 2,035 & 2,571 & 2,355 & 2,204 & 1,980 & 1,730 & 1,741 & 2,310 & 30,47 \\
\hline
\end{tabular}

Panel B. Old Firms

Governance

Position Held by the Controlling Family

0 Neither

1 Only chair

2 Only CEO

3 CEO \& chair

Avg. participation intensity

N

Year Observed

\begin{tabular}{|c|c|c|c|c|c|c|c|c|c|c|c|c|c|c|}
\hline 2000 & 2001 & 2002 & 2003 & 2004 & 2005 & 2006 & 2007 & 2008 & 2009 & 2010 & 2011 & 2012 & 2013 & All \\
\hline $5 \%$ & $5 \%$ & $5 \%$ & $4 \%$ & $5 \%$ & $3 \%$ & $3 \%$ & $2 \%$ & $2 \%$ & $2 \%$ & $2 \%$ & $2 \%$ & $2 \%$ & $2 \%$ & $3 \%$ \\
\hline $9 \%$ & $9 \%$ & $9 \%$ & $11 \%$ & $9 \%$ & $10 \%$ & $11 \%$ & $9 \%$ & $9 \%$ & $9 \%$ & $8 \%$ & $9 \%$ & $10 \%$ & $9 \%$ & $9 \%$ \\
\hline $9 \%$ & $9 \%$ & $8 \%$ & $7 \%$ & $9 \%$ & $7 \%$ & $8 \%$ & $8 \%$ & $8 \%$ & $7 \%$ & $7 \%$ & $7 \%$ & $6 \%$ & $7 \%$ & $7 \%$ \\
\hline $77 \%$ & $78 \%$ & $79 \%$ & $78 \%$ & $77 \%$ & $80 \%$ & $78 \%$ & $81 \%$ & $81 \%$ & $82 \%$ & $83 \%$ & $83 \%$ & $82 \%$ & $82 \%$ & $80 \%$ \\
\hline 2.57 & 2.59 & 2.61 & 2.59 & 2.58 & 2.65 & 2.75 & 2.68 & 2.68 & 2.69 & 2.70 & 2.71 & 2.69 & 2.69 & 2.65 \\
\hline 1,476 & 1,077 & 1,077 & 1,663 & 1,708 & 1,531 & 1,633 & 1,666 & 1,715 & 1,828 & 1,918 & 2,062 & 2,084 & 2,180 & 23,618 \\
\hline
\end{tabular}

Panel C. New Firms vs. Old Firms

\begin{tabular}{|c|c|c|}
\hline \multirow[b]{2}{*}{ Independent Variable } & \multicolumn{2}{|c|}{ Dependent Variable: PARTICIPATION } \\
\hline & New Firms & Old Firms \\
\hline OWNERSHIP & $\begin{array}{l}0.034^{\star \star \star} \\
0.001\end{array}$ & 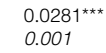 \\
\hline PERFORMANCE & $\begin{array}{l}0.437^{\star \star \star} \\
0.057^{2}\end{array}$ & $\begin{array}{l}0.299^{\star \star \star} \\
0.081\end{array}$ \\
\hline SIZE & $\begin{array}{c}-0.013^{\star \star} \\
0.006\end{array}$ & $\begin{array}{c}-0.191^{\star \star \star} \\
0.013\end{array}$ \\
\hline RISK & $\begin{array}{l}0.103 \\
0.110\end{array}$ & $\begin{array}{c}-0.192^{\star \star \star} \\
0.109\end{array}$ \\
\hline RURAL & $\begin{array}{l}0.069^{\star} \\
0.041\end{array}$ & $\begin{array}{c}-0.082^{\star \star} \\
0.038\end{array}$ \\
\hline $\begin{array}{l}\text { Pseudo- } R^{2} \\
N\end{array}$ & $\begin{array}{r}0.059 \\
21,049\end{array}$ & $\begin{array}{r}0.046 \\
23,628\end{array}$ \\
\hline
\end{tabular}

\section{The Endogeneity of Participation and Performance}

We have repeatedly shown that the controlling family's decision to participate in governance is not exogenous to the firm's performance. Moreover, the family firm literature often finds that performance is not exogenous to participation (O’Boyle et al. (2012), Amit and Villalonga (2014)). Thus, performance 
may matter for participation and participation may matter for performance. In this section, we first test for Granger causality among the main variables in the baseline model. Next, we use instrumental variables (IVs) for performance and participation to estimate the effect of each variable on the other. Using IVs allows us to judge the seriousness of the bias if endogeneity is ignored and to disentangle the two-way relationship between participation and performance by quantifying both effects.

We run panel vector autoregression (VAR) to test for Granger causality (Holtz-Eakin, Newey, and Rosen (1988)), using the code of Love and Zicchino (2006). We use PARTICIPATION, OWNERSHIP, PERFORMANCE, and SIZE as the endogenous variables. The results reported in Table 7 show that lagged OWNERSHIP, PERFORMANCE, and SIZE relate significantly to current PARTICIPATION. In contrast, lagged PARTICIPATION does not relate significantly to current OWNERSHIP, PERFORMANCE, and SIZE. These results suggest that participation intensity is Granger-caused by performance, size, and ownership, while there is no clear support for the converse.

Turning next to the IV approach, we instrument for PERFORMANCE in the participation regression by the economic activity level in the firm's local environment. Our two instruments are the lagged growth rate of employment and the growth rate of value added in the county where the firm is headquartered. Both instruments include family firms, non-family firms, and the public sector in each of the 18 counties. We find that these variables are positively associated with firm performance, suggesting that a better local economic environment benefits the family firm's profitability (relevance condition). In addition, the local economic environment is likely to be taken as exogenously given by the relatively small

\section{TABLE 7}

Tests for Granger Causality

Table 7 presents the estimated coefficients and standard errors of the first lag in panel VARs. PARTICIPATION can take on four different values: 3 if the family has both the CEO and the chair in the firm, 2 if it has only the CEO, 1 if it has only the chair, and 0 if it has neither. OWNERSHIP is the lagged ultimate equity fraction held by the firm's largest family by ownership. PERFORMANCE is operating earnings after taxes divided by total assets in real terms averaged over the past 3 years, while SIZE is the lagged natural log of real sales in millions of NOK as of year-end 2013. PERFORMANCE and SIZE are both winsorized at the $1 \%$ and $99 \%$ tails. The sample consists of all private Norwegian family firms with limited liability over the period 2001-2013. We exclude financials, utilities, and subsidiaries, and we require positive assets, sales, and employment. A family is a group of owning individuals in the firm who are related by blood or marriage up to the fourth degree of kinship. A family firm is a firm in which the ultimate equity share of the largest family by ownership exceeds $50 \%$. The models have time dummies and industry dummies. AGE and RURAL are included as exogenous variables, where AGE is the natural log of the number of years since the firm was founded and RURAL is a dummy variable that is 1 if and only if the family firm is located outside Norway's five largest cities. We report standard errors clustered at the firm level (in italics). ${ }^{*}$ and ${ }^{* *}$ indicate coefficients with $t$-values statistically different from 0 at the $5 \%$ and $1 \%$ levels, respectively.

Dependent Variable

\begin{tabular}{|c|c|c|c|c|}
\hline Independent Variable & PARTICIPATION & OWNERSHIP & PERFORMANCE & SIZE \\
\hline PARTICIPATION & $\begin{array}{l}0.836^{\star \star} \\
0.016\end{array}$ & $\begin{array}{l}0.002 \\
0.002\end{array}$ & $\begin{array}{l}0.006 \\
0.009\end{array}$ & $\begin{array}{l}0.046 \\
0.039\end{array}$ \\
\hline OWNERSHIP & $\begin{array}{l}0.225^{\star} \\
0.091\end{array}$ & $\begin{array}{l}0.858^{\star *} \\
0.011\end{array}$ & $\begin{array}{l}0.138^{*} \\
0.061\end{array}$ & $\begin{array}{r}-0.249 \\
0.219\end{array}$ \\
\hline PERFORMANCE & $\begin{array}{l}0.191^{*} \\
0.097\end{array}$ & $\begin{array}{r}-0.020 \\
0.012\end{array}$ & $\begin{array}{l}0.199^{*} \\
0.098\end{array}$ & $\begin{array}{r}-0.027 \\
0.254\end{array}$ \\
\hline SIZE & $\begin{array}{c}-0.456^{\star \star} \\
0.154\end{array}$ & $\begin{array}{r}-0.001 \\
0.019\end{array}$ & $\begin{array}{l}0.316^{\star *} \\
0.107\end{array}$ & $\begin{array}{r}-0.715^{\star} \\
0.353\end{array}$ \\
\hline
\end{tabular}


family firms in our sample. Therefore, we argue that the instruments for performance affect family participation only through firm performance (exclusion condition).

We instrument for PARTICIPATION in the performance regression by the number of members in the controlling family. Larger families are more likely to have qualified candidates who are willing to participate in the firm's governance. A larger family also means that a smaller proportion of the family's human capital is invested in the firm when family members serve as CEOs or chairs. These properties reduce the risk faced by the family as a whole. By including both the family members who are shareholders in the firm and those who are not, we avoid potential endogeneity problems within the family regarding who chooses to become a shareholder. The importance of family size for family participation is also supported by evidence in Cao, Cumming, and Wang (2015), who use the one-child policy in China as a natural experiment. They find that this event is associated with less subsequent family participation in family firms.

We find that family size is positively correlated with the family's participation (relevance). In contrast, family size, and particularly the size of the extended family we consider here, is unlikely to affect firm performance except through family participation (exclusion).

As with the family's participation decision, the family firm's profitability may depend on the firm's size, risk, age, industry, and calendar year. Therefore, we use the same control variables in both regressions. ${ }^{16}$

We want to compare the relative strength of the two effects going from participation to performance and from performance to participation. Therefore, we standardize the observed value of every variable at the firm level by deducting the mean and dividing the difference by the standard deviation. The results are reported in Table 8, which shows the estimated participation regressions and performance regressions, using alternatively the raw (observed) and the instrumented independent variable in question.

Comparing the estimates for the raw and the instrumented independent variables under a given dependent variable, the table shows that the estimates are heavily biased downward if we ignore endogeneity and use the raw independent variables. Specifically, the coefficient for PERFORMANCE in the participation regression using RAW_PERFORMANCE is just 5\% of the coefficient using INSTRUMENTED_PERFORMANCE. Similarly, the coefficient for PARTICIPATION in the performance regression using RAW_PARTICIPATION is just $21 \%$ of the coefficient using INSTRUMENTED_PARTICIPATION. The Hausman test confirms that the coefficients are significantly different when using the instrumented variables rather than the raw variables. For the participation equation, which uses two instruments for performance, the overidentification test shows that these instruments are valid $(p=0.322)$.

\footnotetext{
${ }^{16}$ Because RISK uses the firm's sales during the past 3 years, only firms that have been active for at least 3 years are included in the sample. If we ignore RISK in the regressions, the very youngest firms become included and sample size increases. Unreported results show that the estimated coefficients for the remaining variables are qualitatively unchanged. This result suggests that the effect of RISK is orthogonal to the effect of the other variables and that the very youngest firms do not differ from the other firms regarding the relationship between participation and performance.
} 
TABLE 8

The Two-Way Relationship between Participation Intensity and Performance

Table 8 shows the relationship between participation and performance, allowing for two-way relationships between the two. RAW_PERFORMANCE is operating earnings after taxes divided by total assets in real terms averaged over the past 3 years, while INSTRUMENTED_PERFORMANCE is performance estimated in the first step of the 2-stage least squares (2SLS), where the instruments for performance are the lagged growth rate of employment in the county where the firm is headquartered and the growth rate of the value added in the same county. RAW_PARTICIPATION can take on four different values: 3 if the family has both the CEO and the chair, 2 if it has only the CEO, 1 if it has only the chair, and 0 if the family holds neither position. INSTRUMENTED_PARTICIPATION is participation estimated in the first step of the 2SLS, where the instrument for participation is the number of family members in the controlling family. OWNERSHIP is the lagged ultimate equity fraction held by the firm's largest family by ownership. PERFORMANCE is operating earnings after taxes divided by total assets in real terms averaged over the past 3 years, while SIZE is the lagged natural log of real sales in millions of NOK as of year-end 2013. PERFORMANCE and SIZE are both winsorized at the $1 \%$ and $99 \%$ tails. AGE is the natural log of the number of years since the firm was founded, while RISK is the natural log of the ratio between the standard deviation of sales and the mean sales over the previous 3 years. RURAL is a dummy variable that is 1 if and only if the family firm is located outside Norway's five largest cities. All variables are standardized. The sample consists of all private Norwegian family firms with limited liability during 2001-2013. We exclude financials, utilities, and subsidiaries, and we require positive assets, sales, and employment. A family firm is a firm in which the ultimate equity share of the largest family by ownership exceeds $50 \%$. A family is a group of owning individuals in the firm who are related by blood or marriage up to the fourth degree of kinship. All regressions include industry dummies and time dummies, and standard errors are clustered at the firm level. The standard error is reported in italics below the estimated coefficient. *, ${ }^{* *}$, and ${ }^{* * *}$ indicate coefficients with $t$-values statistically different from 0 at the $10 \%, 5 \%$, and $1 \%$ levels, respectively.

\begin{tabular}{|c|c|c|c|c|}
\hline \multirow[b]{3}{*}{ Independent Variable } & \multicolumn{4}{|c|}{ Dependent Variable } \\
\hline & \multicolumn{2}{|c|}{ PARTICIPATION } & \multicolumn{2}{|c|}{ PERFORMANCE } \\
\hline & $\begin{array}{c}\text { RAW } \\
\text { PERFORMANCE } \\
\end{array}$ & $\begin{array}{l}\text { INSTRUMENTED_- } \\
\text { PERFORMANCE }\end{array}$ & $\begin{array}{c}\text { RAW }_{-} \\
\text {PARTICIPATION } \\
\end{array}$ & $\begin{array}{l}\text { INSTRUMENTED } \\
\text { PARTICIPATION } \\
\end{array}$ \\
\hline PERFORMANCE & $\begin{array}{l}0.022^{\star \star \star} \\
0.001\end{array}$ & $\begin{array}{l}0.367^{* *} \\
0.183\end{array}$ & & \\
\hline PARTICIPATION & & & $\begin{array}{l}0.050^{\star \star \star *} \\
0.002\end{array}$ & $\begin{array}{l}0.189^{\star \star \star} \\
0.033\end{array}$ \\
\hline OWNERSHIP & $\begin{array}{l}0.259^{\star \star \star} \\
0.002\end{array}$ & $\begin{array}{l}0.256^{\star \star \star} \\
0.003\end{array}$ & $\begin{array}{c}-0.006^{*} \\
0.003\end{array}$ & $\begin{array}{l}-0.042^{\star \star \star} \\
0.009\end{array}$ \\
\hline SIZE & $\begin{array}{l}-0.030^{\star \star \star} \\
0.001\end{array}$ & $\begin{array}{l}-0.078^{\star * *} \\
0.024\end{array}$ & $\begin{array}{l}0.137^{\star \star \star} \\
0.002\end{array}$ & $\begin{array}{l}0.141^{\star \star \star} \\
0.002\end{array}$ \\
\hline AGE & $\begin{array}{r}-0.001 \\
0.001\end{array}$ & $\begin{array}{r}-0.002 \\
0.002\end{array}$ & $\begin{array}{l}0.011^{\star \star \star} \\
0.002\end{array}$ & $\begin{array}{l}0.011^{\star \star \star} \\
0.001\end{array}$ \\
\hline RISK & $\begin{array}{l}-0.017^{\star \star \star} \\
0.001\end{array}$ & $\begin{array}{l}0.007 \\
0.013\end{array}$ & $\begin{array}{l}-0.062^{\star \star \star} \\
0.002\end{array}$ & $\begin{array}{l}-0.059^{\star \star \star} \\
0.002\end{array}$ \\
\hline RURAL & $\begin{array}{l}0.008^{\star *} \\
0.002\end{array}$ & $\begin{array}{l}0.019^{* *} \\
0.007\end{array}$ & $\begin{array}{l}-0.038^{\star \star \star *} \\
0.003\end{array}$ & $\begin{array}{l}-0.039^{\star \star \star} \\
0.003\end{array}$ \\
\hline $\begin{array}{l}F \\
P(F)\end{array}$ & $\begin{array}{r}854 \\
0.000\end{array}$ & & $\begin{array}{r}452 \\
0.000\end{array}$ & \\
\hline $\begin{array}{l}\text { Wald } \chi^{2} \\
P>\text { Wald } \chi^{2}\end{array}$ & & $\begin{array}{r}14,331 \\
0.000\end{array}$ & & $\begin{array}{r}11,243 \\
0.000\end{array}$ \\
\hline $\begin{array}{l}R^{2} \\
\text { Hausman test for equality } \\
\text { of coefficients, } \chi^{2}\end{array}$ & 0.053 & $\begin{array}{l}0.040 \\
60^{\star \star \star}\end{array}$ & 0.030 & $\begin{array}{l}0.020 \\
130^{\star \star \star}\end{array}$ \\
\hline$N$ & 397,578 & 331,943 & 397,578 & 397,204 \\
\hline
\end{tabular}

Regarding two-way causation, the models using an instrumented independent variable have a coefficient value of 0.367 for PERFORMANCE and 0.189 for PARTICIPATION. Thus, the effect running from PERFORMANCE to PARTICIPATION is twice as large as the effect running from participation to performance. When returns on assets increase by 1 standard deviation, expected participation increases by one-third of its standard deviation. This result suggests there is indeed two-way causation. Importantly, these figures reflect that the strongest effect is due to the family's use of performance to self-select into participation rather than due to the family's participation per se.

While the results in Table 8 are from a model using four alternative participation intensities, the existing literature measures participation more narrowly by mostly studying whether the family holds just one position, normally the CEO 
(O'Boyle et al. (2012), Amit and Villalonga (2014)). Panel A of Table 9 shows estimates of a model that captures this situation. Because the dependent variable is a dummy variable (family CEO/non-family CEO), we also show the results for probit regressions.

As in Table 8, the estimated relationship between PERFORMANCE and PARTICIPATION is stronger when using IVs rather than raw variables. Moreover, the effect going from PERFORMANCE to PARTICIPATION is stronger than the effect going the opposite way.

Finally, Panel B of Table 9 shows the estimates of corresponding models for the chair position. As in Panel A, we find that exogenous PERFORMANCE

\section{TABLE 9}

The Two-Way Relationship between Performance and Family Participation as CEO or Chair

Table 9 shows the relationship between performance and family participation as CEO or chair, allowing for two-way relationships. RAW_PERFORMANCE is operating earnings after taxes divided by total assets in real terms averaged over the past 3 years, while INSTRUMENTED_PERFORMANCE is performance estimated in the first step of the 2SLS, where the instruments for performance are the lagged growth rate of employment in the county where the firm is headquartered and the growth rate of the value added in the same county. RAW_PARTICIPATION is a dummy variable equal to 1 if the controlling family has the CEO position (Panel A) or the chair position (Panel B). INSTRUMENTED_PARTICIPATION is participation estimated in the first step of the 2SLS, where the instrument for participation is the number of family members in the controlling family. OWNERSHIP is the lagged ultimate equity fraction held by the firm's largest family by ownership. PERFORMANCE is operating earnings after taxes divided by total assets in real terms averaged over the past 3 years, while SIZE is the lagged natural log of real sales in millions of NOK as of year-end 2013. PERFORMANCE and SIZE are both winsorized at the $1 \%$ and $99 \%$ tails. AGE is the natural log of the number of years since the firm was founded, while RISK is the natural log of the ratio between the standard deviation of sales and the mean sales over the previous 3 years. RURAL is a dummy variable that is 1 if and only if the family firm is located outside Norway's five largest cities. All variables are standardized. The sample consists of all private Norwegian family firms with limited liability during 2001-2013. We exclude financials, utilities, and subsidiaries, and we require positive assets, sales, and employment. A family firm is a firm in which the ultimate equity share of the largest family by ownership exceeds $50 \%$. A family is a group of owning individuals in the firm who are related by blood or marriage up to the fourth degree of kinship. All regressions include industry dummies and time dummies, and standard errors are clustered at the firm level. The standard error is reported in italics below the estimated coefficient. ${ }^{*},{ }^{* *}$, and ${ }^{* * *}$ indicate coefficients with $t$-values statistically different from 0 at the $10 \%, 5 \%$, and $1 \%$ levels, respectively.

\begin{tabular}{|c|c|c|c|c|c|c|}
\hline \multirow[b]{4}{*}{ Independent Variable } & \multicolumn{4}{|c|}{ Least Squares Estimation } & \multicolumn{2}{|c|}{ Probit Estimation } \\
\hline & \multicolumn{6}{|c|}{ Dependent Variable } \\
\hline & \multicolumn{2}{|c|}{ PARTICIPATION } & \multicolumn{2}{|c|}{ PERFORMANCE } & \multicolumn{2}{|c|}{ PARTICIPATION } \\
\hline & $\begin{array}{c}\text { RAW } \\
\text { PERFORMANCE } \\
\end{array}$ & $\begin{array}{l}\text { INSTRUMENTED_- } \\
\text { PERFORMANCE } \\
\end{array}$ & $\begin{array}{c}\text { RAW } \\
\text { PARTICIPATION } \\
\end{array}$ & $\begin{array}{l}\text { INSTRUMENTED_ } \\
\text { PARTICIPATION } \\
\end{array}$ & $\begin{array}{c}\text { RAW } \\
\text { PERFORMANCE } \\
\end{array}$ & $\begin{array}{l}\text { INSTRUMENTED } \\
\text { PERFORMANCE } \\
\end{array}$ \\
\hline \multicolumn{7}{|l|}{ Panel A. Family CEO } \\
\hline PERFORMANCE & $\begin{array}{l}0.020^{\star \star \star} \\
0.001\end{array}$ & $\begin{array}{l}0.504^{\star \star} \\
0.233\end{array}$ & & & $\begin{array}{l}0.038^{\star \star \star} \\
0.003\end{array}$ & $\begin{array}{l}0.762^{\star \star \star} \\
0.183\end{array}$ \\
\hline PARTICIPATION & & & $\begin{array}{l}0.050^{\star \star \star} \\
0.002\end{array}$ & $\begin{array}{l}0.206^{\star \star \star} \\
0.036\end{array}$ & & \\
\hline OWNERSHIP & $\begin{array}{l}0.195^{\star \star \star} \\
0.002\end{array}$ & $\begin{array}{l}0.120^{\star \star \star} \\
0.004\end{array}$ & $\begin{array}{l}0.001 \\
0.003\end{array}$ & $\begin{array}{l}-0.033^{\star \star \star} \\
0.008\end{array}$ & $\begin{array}{l}0.332^{\star \star \star} \\
0.004\end{array}$ & $\begin{array}{l}0.237^{\star \star \star} \\
0.058\end{array}$ \\
\hline SIZE & $\begin{array}{c}-0.004^{\star \star \star} \\
0.002\end{array}$ & $\begin{array}{c}-0.070^{* *} \\
0.032\end{array}$ & $\begin{array}{l}0.136^{\star \star \star} \\
0.002\end{array}$ & $\begin{array}{l}0.136^{\star \star \star} \\
0.002\end{array}$ & $\begin{array}{l}-0.007^{* *} \\
0.003\end{array}$ & $\begin{array}{c}-0.105^{\star \star \star} \\
0.023\end{array}$ \\
\hline AGE & $\begin{array}{c}-0.004^{\star \star \star} \\
0.004\end{array}$ & $\begin{array}{l}-0.006^{\star \star} \\
0.002\end{array}$ & $\begin{array}{l}0.011^{\star \star \star} \\
0.002\end{array}$ & $\begin{array}{l}0.012^{\star \star \star} \\
0.002\end{array}$ & $\begin{array}{c}-0.009^{\star \star \star} \\
0.003\end{array}$ & $\begin{array}{c}-0.010^{\star \star \star} \\
0.003\end{array}$ \\
\hline RISK & $\begin{array}{c}-0.013^{\star \star \star} \\
0.001\end{array}$ & $\begin{array}{l}0.021 \\
0.017\end{array}$ & $\begin{array}{c}-0.062^{\star \star \star} \\
0.002\end{array}$ & $\begin{array}{l}-0.059^{\star \star \star} \\
0.002\end{array}$ & $\begin{array}{l}-0.026^{\star \star \star} \\
0.002\end{array}$ & $\begin{array}{l}0.033^{*} \\
0.017\end{array}$ \\
\hline RURAL & $\begin{array}{l}0.021^{\star \star \star} \\
0.003\end{array}$ & $\begin{array}{l}0.037^{\star \star \star} \\
0.010\end{array}$ & $\begin{array}{c}-0.038^{\star \star \star} \\
0.004\end{array}$ & $\begin{array}{l}-0.042^{\star \star \star} \\
0.003\end{array}$ & $\begin{array}{l}0.043^{\star \star \star} \\
0.005\end{array}$ & $\begin{array}{l}0.056^{\star \star \star} \\
0.005\end{array}$ \\
\hline $\begin{array}{l}F \\
P(F)\end{array}$ & $\begin{array}{r}854 \\
0.000\end{array}$ & & $\begin{array}{r}444 \\
0.000\end{array}$ & & & \\
\hline $\begin{array}{l}x^{2} \\
P>x^{2}\end{array}$ & & $\begin{array}{r}14,331 \\
0.000\end{array}$ & & $\begin{array}{r}11,243 \\
0.000\end{array}$ & $\begin{array}{l}8,213 \\
0.000\end{array}$ & $\begin{array}{r}17,788 \\
0.000\end{array}$ \\
\hline $\begin{array}{l}R^{2} \\
\text { Hausman test for equality } \\
\text { of coefficients, } \chi^{2}\end{array}$ & 0.024 & $\begin{array}{c}0.030 \\
40.65^{\star \star \star}\end{array}$ & 0.030 & $\begin{array}{c}0.020 \\
89.75^{\star \star \star}\end{array}$ & 0.025 & $\begin{array}{c}0.030 \\
145.87^{\star \star \star}\end{array}$ \\
\hline N & 397,578 & 331,943 & 397,578 & 397,204 & 397,578 & 331,943 \\
\hline
\end{tabular}


TABLE 9 (continued)

The Two-Way Relationship between Performance and Family Participation as CEO or Chair

\begin{tabular}{|c|c|c|c|c|c|c|}
\hline \multirow[b]{4}{*}{ Independent Variable } & \multicolumn{4}{|c|}{ Least Squares Estimation } & \multicolumn{2}{|c|}{ Probit Estimation } \\
\hline & \multicolumn{6}{|c|}{ Dependent Variable } \\
\hline & \multicolumn{2}{|c|}{ PARTICIPATION } & \multicolumn{2}{|c|}{ PERFORMANCE } & \multicolumn{2}{|c|}{ PARTICIPATION } \\
\hline & $\begin{array}{l}\text { RAW } \\
\text { PERFORMANCE }\end{array}$ & $\begin{array}{l}\text { INSTRUMENTED_- } \\
\text { PERFORMANCE }\end{array}$ & $\begin{array}{c}\text { RAW } \\
\text { PARTICIPATION }\end{array}$ & $\begin{array}{l}\text { INSTRUMENTED_ } \\
\text { PARTICIPATION }\end{array}$ & $\begin{array}{l}\text { RAW } \\
\text { PERFORMANCE }\end{array}$ & $\begin{array}{l}\text { INSTRUMENTED_- } \\
\text { PERFORMANCE }\end{array}$ \\
\hline \multicolumn{7}{|l|}{ Panel B. Family Chair } \\
\hline PERFORMANCE & $\begin{array}{l}0.021^{\star \star \star} \\
0.001\end{array}$ & $\begin{array}{l}0.016^{\star \star} \\
0.007\end{array}$ & & & $\begin{array}{l}0.060^{\star \star \star} \\
0.003\end{array}$ & $\begin{array}{l}0.109^{\star \star} \\
0.051\end{array}$ \\
\hline PARTICIPATION & & & $\begin{array}{l}0.043^{\star \star \star} \\
0.002\end{array}$ & $\begin{array}{l}0.189^{\star \star \star} \\
0.033\end{array}$ & & \\
\hline OWNERSHIP & $\begin{array}{l}0.347^{\star \star \star} \\
0.002\end{array}$ & $\begin{array}{l}0.345^{\star \star \star} \\
0.003\end{array}$ & $\begin{array}{c}-0.008^{\star \star} \\
0.003\end{array}$ & $\begin{array}{c}-0.059^{\star \star \star} \\
0.012\end{array}$ & $\begin{array}{l}0.659^{\star \star \star} \\
0.005\end{array}$ & $\begin{array}{l}0.665^{\star \star \star} \\
0.022\end{array}$ \\
\hline SIZE & $\begin{array}{l}-0.079^{\star \star \star} \\
0.001\end{array}$ & $\begin{array}{l}-0.082^{\star \star} \\
0.082\end{array}$ & $\begin{array}{l}0.139^{\star \star \star} \\
0.002\end{array}$ & $\begin{array}{l}0.150^{\star \star \star} \\
0.003\end{array}$ & $\begin{array}{l}-0.221^{\star \star \star} \\
0.004\end{array}$ & $\begin{array}{l}-0.245^{\star \star \star} \\
0.023\end{array}$ \\
\hline AGE & $\begin{array}{l}0.004^{\star \star \star} \\
0.001\end{array}$ & $\begin{array}{c}-0.005^{\star \star} \\
0.002\end{array}$ & $\begin{array}{l}0.011^{\star \star \star} \\
0.002\end{array}$ & $\begin{array}{l}0.010^{\star \star \star} \\
0.002\end{array}$ & $\begin{array}{l}0.010^{\star \star \star} \\
0.003\end{array}$ & $\begin{array}{l}0.014^{\star \star} \\
0.006\end{array}$ \\
\hline RISK & $\begin{array}{c}-0.023^{\star \star \star} \\
0.001\end{array}$ & $\begin{array}{c}-0,024^{\star \star} \\
0.012\end{array}$ & $\begin{array}{c}-0.061^{\star \star \star} \\
0.002\end{array}$ & $\begin{array}{c}-0.058^{\star \star \star} \\
0.002\end{array}$ & $\begin{array}{l}-0.051^{\star \star \star} \\
0.004\end{array}$ & $\begin{array}{l}0.054 \\
0.042\end{array}$ \\
\hline RURAL & $\begin{array}{l}0.023^{\star \star \star} \\
0.002\end{array}$ & $\begin{array}{c}-0,022^{\star \star \star} \\
0.007\end{array}$ & $\begin{array}{c}-0.036^{\star \star \star} \\
0.003\end{array}$ & $\begin{array}{c}-0.033^{\star \star \star} \\
0.003\end{array}$ & $\begin{array}{l}0.056^{\star \star \star} \\
0.006\end{array}$ & $\begin{array}{l}0.054^{\star \star} \\
0.024\end{array}$ \\
\hline $\begin{array}{l}F \\
P(F)\end{array}$ & $\begin{array}{l}1,365 \\
0.000\end{array}$ & & $\begin{array}{r}450 \\
0.000\end{array}$ & & & \\
\hline $\begin{array}{l}\chi^{2} \\
P>\chi^{2}\end{array}$ & & $\begin{array}{r}29,772 \\
0.000\end{array}$ & & $\begin{array}{r}11,217 \\
0.000\end{array}$ & $\begin{array}{r}26,865 \\
0.000\end{array}$ & $\begin{array}{r}21,851 \\
0.000\end{array}$ \\
\hline $\begin{array}{l}R^{2} \\
\text { Hausman test for equality } \\
\text { of coefficients, } \chi^{2}\end{array}$ & 0.082 & $\begin{array}{c}0.083 \\
119.97^{\star \star \star}\end{array}$ & 0.029 & $\begin{array}{c}0.018 \\
128.98^{\star \star \star}\end{array}$ & 0.110 & $\begin{array}{c}0.110 \\
162.42^{\star \star \star}\end{array}$ \\
\hline$N$ & 397,578 & 331,943 & 397,578 & 397,204 & 397,578 & 331,943 \\
\hline
\end{tabular}

matters for family PARTICIPATION, although the effect is not as strong as for the CEO position.

These results are consistent with Bennedsen et al. (2007), who find that CEO succession within the family is more common when the firm is already doing well. Using the sample of all family firms in the economy, we show that high, exogenous firm performance increases the likelihood of having not just a family CEO but of having more intensive family participation in a more comprehensive sense. We also document that there is two-way causation and that the stronger effect runs from performance to participation.

Summarizing this section, we have found two-way causation between the controlling family's participation intensity and the family firm's performance. The effect of performance on participation is stronger, and the estimated relationship between performance and participation will be heavily biased if the endogenous nature of participation is ignored.

\section{Conclusions}

This paper documents that family firms are more intensively governed by the controlling family the greater the family's ownership percentage, the more profitable the firm, the smaller the firm's size, and the lower the firm's risk. These relationships are insensitive to how we define a family firm, to whether we analyze family firms with or without shareholder conflicts, and to how we measure family participation. There is no evidence of a life-cycle effect because the relationship between family participation and family firm characteristics is very similar in young and old firms. 
These results are consistent with the notion that the controlling family's decision to participate in the family firm's governance depends on observable characteristics of the firm. The family seems to condition its participation decision on firm characteristics that matter for the costs and benefits of participation, that vary with the intensity of participation, and that seldom change dramatically from one year to the next. This regularity means that family governance is not random relative to firm outcomes.

Accounting for the endogenous nature of corporate governance is rare in studies of how the controlling family's participation intensity interacts with the firm's performance. Our evidence provides a plausible explanation for why this voluminous literature has produced such ambiguous results. By documenting how governance effort is driven by firm characteristics, such as performance, our evidence supports the recent insight that the failure to account for this self-selection may produce incorrect inferences about the merits of family firm governance. In particular, we find that there is two-way causation between participation and performance, that the estimates will be biased if this endogeneity is ignored, and that the stronger effect runs from performance to participation rather than the opposite way. These results strengthen the impression that it is crucial to account for the endogenous nature of the controlling family's participation in governance when analyzing the behavior of family firms.

\section{Appendix. Supplementary Tables}

TABLE A1

Controlling Family's Participation Intensity by Firm Size

Table A1 shows how the controlling family's participation intensity in the family firm's governance varies with the size of the firm as measured by sales. PARTICIPATION can take on four different values: 3 if the family has both the CEO and the chair, 2 if the family has only the CEO, 1 if the family has only the chair, and 0 if the family holds neither position. NO_PARTICIPATION means the family has neither the CEO nor the chair position. FAMILY_EQUITY_STAKE is the controlling family's ultimate ownership fraction in the firm. SALES is measured in millions of NOK as of year-end 2013. Multiple-owner firms have at least one minority shareholder, while single-owner firms have no minority shareholder. The sample consists of all private Norwegian family firms with limited liability in 2001-2013. We exclude financials, utilities, and subsidiaries, and we require positive assets, sales, and employment. A family firm is a firm in which the ultimate equity share of the largest family by ownership exceeds $50 \%$. A family is a group of owning individuals in the firm who are related by blood or marriage up to the fourth degree of kinship. * and ${ }^{* *}$ indicate $t$-values statistically different from 0 at the $5 \%$ and $1 \%$ levels, respectively.

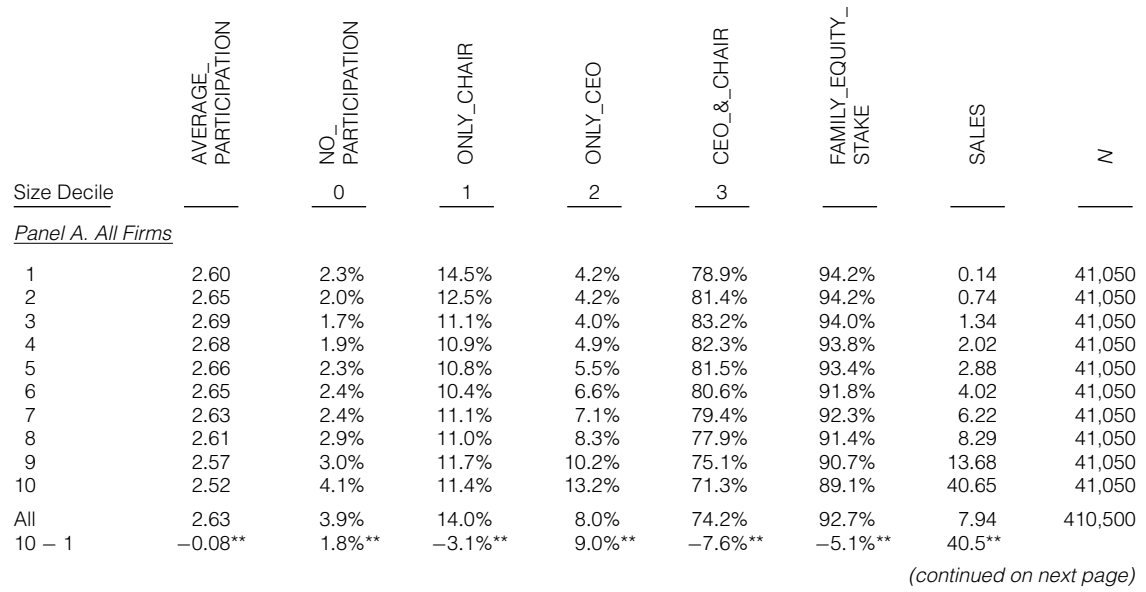


2112 Journal of Financial and Quantitative Analysis

TABLE A1 (continued)

Controlling Family's Participation Intensity by Firm Size

\begin{tabular}{|c|c|c|c|c|c|c|c|c|}
\hline & 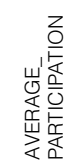 & 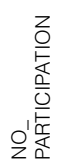 & $\begin{array}{l}\frac{9}{4} \\
\frac{1}{0} \\
\underbrace{}_{1} \\
\frac{1}{2} \\
0\end{array}$ & 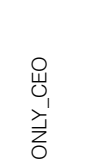 & 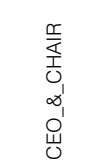 & 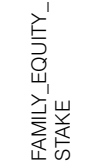 & $\begin{array}{l}\stackrel{\varpi}{\rightleftarrows} \\
\frac{\mathbb{4}}{\omega}\end{array}$ & z \\
\hline Size Decile & & 0 & 1 & 2 & 3 & & & \\
\hline \multicolumn{9}{|c|}{ Panel B. Multiple-Owner Firms } \\
\hline 1 & 2.43 & $5.0 \%$ & $16.1 \%$ & $9.5 \%$ & $69.3 \%$ & $74.1 \%$ & 0.18 & 10,901 \\
\hline 2 & 2.46 & $4.8 \%$ & $14.7 \%$ & $9.9 \%$ & $70.6 \%$ & $72.3 \%$ & 0.92 & 10,901 \\
\hline 3 & 2.48 & $4.4 \%$ & $13.5 \%$ & $11.9 \%$ & $70.2 \%$ & $71.9 \%$ & 1.70 & 10,901 \\
\hline 4 & 2.42 & $5.4 \%$ & $14.2 \%$ & $13.5 \%$ & $66.9 \%$ & $72.1 \%$ & 2.63 & 10,901 \\
\hline 5 & 2.42 & $5.5 \%$ & $13.6 \%$ & $14.4 \%$ & $66.6 \%$ & $72.5 \%$ & 3.81 & 10,901 \\
\hline 6 & 2.40 & $5.6 \%$ & $14.2 \%$ & $15.1 \%$ & $65.1 \%$ & $72.8 \%$ & 5.33 & 10,901 \\
\hline 7 & 2.38 & $5.8 \%$ & $14.5 \%$ & $15.4 \%$ & $64.3 \%$ & $72.4 \%$ & 7.46 & 10,901 \\
\hline 8 & 2.36 & $5.8 \%$ & $14.8 \%$ & $17.4 \%$ & $61.9 \%$ & $72.9 \%$ & 10.80 & 10,901 \\
\hline 9 & 2.31 & $6.3 \%$ & $16.0 \%$ & $18.2 \%$ & $59.5 \%$ & $72.8 \%$ & 17.43 & 10,901 \\
\hline 10 & 2.19 & $8.5 \%$ & $15.8 \%$ & $23.5 \%$ & $52.2 \%$ & $72.8 \%$ & 48.51 & 10,901 \\
\hline All & 2.39 & $5.7 \%$ & $14.7 \%$ & $14.9 \%$ & $64.7 \%$ & $72.6 \%$ & 9.88 & 109,010 \\
\hline $10-1$ & $-0.24^{\star *}$ & $3.4 \%^{\star \star *}$ & $-0.31 \%$ & $14.0 \%{ }^{* *}$ & $-17.1 \%^{\star \star *}$ & $-1.3 \%^{* \star}$ & $48.3^{\star \star}$ & \\
\hline \multicolumn{9}{|c|}{ Panel C. Single-Owner Firms } \\
\hline 1 & 2.64 & $1.5 \%$ & $14.1 \%$ & $2.8 \%$ & $81.6 \%$ & $100.0 \%$ & 0.12 & 30,131 \\
\hline 2 & 2.70 & $1.2 \%$ & $11.8 \%$ & $2.5 \%$ & $84.5 \%$ & $100.0 \%$ & 0.68 & 30,124 \\
\hline 3 & 2.73 & $1.1 \%$ & $10.7 \%$ & $2.3 \%$ & $85.9 \%$ & $100.0 \%$ & 1.25 & 30,125 \\
\hline 4 & 2.74 & $1.1 \%$ & $10.1 \%$ & $2.5 \%$ & $86.3 \%$ & $100.0 \%$ & 1.86 & 30,136 \\
\hline 5 & 2.74 & $1.3 \%$ & $9.7 \%$ & $2.9 \%$ & $86.1 \%$ & $100.0 \%$ & 2.62 & 30,122 \\
\hline 6 & 2.74 & $1.2 \%$ & $9.4 \%$ & $3.4 \%$ & $86.0 \%$ & $100.0 \%$ & 3.64 & 30,128 \\
\hline 7 & 2.72 & $1.3 \%$ & $9.9 \%$ & $3.9 \%$ & $84.9 \%$ & $100.0 \%$ & 5.08 & 30,128 \\
\hline 8 & 2.73 & $1.4 \%$ & $9.5 \%$ & $4.3 \%$ & $84.8 \%$ & $100.0 \%$ & 7.43 & 30,128 \\
\hline 9 & 2.70 & $1.5 \%$ & $9.6 \%$ & $6.0 \%$ & $83.0 \%$ & $100.0 \%$ & 12.26 & 30,128 \\
\hline 10 & 2.68 & $2.0 \%$ & $9.1 \%$ & $8.2 \%$ & $80.7 \%$ & $100.0 \%$ & 38.27 & 30,128 \\
\hline & 2.71 & $1.4 \%$ & $10.4 \%$ & $3.9 \%$ & $84.4 \%$ & $100.0 \%$ & 7.24 & 301,278 \\
\hline $10-1$ & 0.03 & $0.5 \%^{* * k}$ & $-5.1 \%^{\star *}$ & $5.4 \%^{* *}$ & $-0.9 \%$ * & $0.0 \%$ & $38.2^{\star \star}$ & \\
\hline
\end{tabular}




\section{TABLE A2}

\section{Correlations}

Table A2 shows the Pearson correlation coefficients between pairs of potential determinants of the controlling family's decision to govern the family firm. PARTICIPATION can take on four different values: 3 if the family has both the CEO and the chair, 2 if the family has only the CEO, 1 if the family has only the chair, and 0 if the family holds neither position. OWNERSHIP is the lagged ultimate equity fraction held by the firm's largest family by ownership. PERFORMANCE is operating earnings after taxes divided by total assets in real terms averaged over the past 3 years, while SIZE is the lagged natural log of real sales in millions of NOK as of year-end 2013. PERFORMANCE and SIZE are both winsorized at the $1 \%$ and $99 \%$ tails. AGE is the natural log of the number of years since the firm was founded, while RISK is the natural log of the ratio between the standard deviation of sales and the mean sales over the previous 3 years. RURAL is a dummy variable that is 1 if and only if the family firm is located outside Norway's five largest cities. The sample consists of all private Norwegian family firms with limited liability. The sample period is 2001-2013 in Panel A and 2013 in Panel B. We exclude financials, utilities, and subsidiaries, and we require positive assets, sales, and employment. A family firm is a firm in which the ultimate equity share of the largest family by ownership exceeds $50 \%$. A family is a group of owning individuals in the firm who are related by blood or marriage up to the fourth degree of kinship.

\begin{tabular}{|c|c|c|c|c|c|c|c|}
\hline & 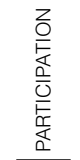 & 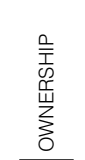 & 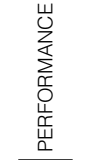 & $\frac{\frac{U}{N}}{\omega}$ & 岕 & $\frac{r}{\frac{b}{c}}$ & 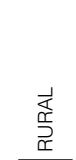 \\
\hline \multicolumn{8}{|l|}{ Panel A. All Years } \\
\hline $\begin{array}{l}\text { PARTICIPATION } \\
\text { OWNERSHIP } \\
\text { PERFORMANCE } \\
\text { SIZE } \\
\text { AGE } \\
\text { RISK } \\
\text { RURAL }\end{array}$ & $\begin{array}{r}1.000 \\
0.205 \\
0.026 \\
-0.042 \\
0.008 \\
-0.031 \\
0.018\end{array}$ & $\begin{array}{r}0.205 \\
1.000 \\
-0.003 \\
-0.079 \\
0.018 \\
-0.003 \\
0.050\end{array}$ & $\begin{array}{r}0.026 \\
-0.003 \\
1.000 \\
0.211 \\
0.028 \\
-0.131 \\
-0.022\end{array}$ & $\begin{array}{r}-0.042 \\
-0.079 \\
0.211 \\
1.000 \\
0.080 \\
-0.312 \\
-0.086\end{array}$ & $\begin{array}{r}0.008 \\
0.018 \\
0.028 \\
0.080 \\
1.000 \\
-0.083 \\
-0.036\end{array}$ & $\begin{array}{r}-0.031 \\
-0.003 \\
-0.131 \\
-0.312 \\
-0.083 \\
1.000 \\
-0.067\end{array}$ & $\begin{array}{r}0.018 \\
0.050 \\
-0.022 \\
-0.086 \\
-0.036 \\
-0.067 \\
1.000\end{array}$ \\
\hline \multicolumn{8}{|l|}{ Panel B. Final Year } \\
\hline $\begin{array}{l}\text { PARTICIPATION } \\
\text { OWNERSHIP } \\
\text { PERFORMANCE } \\
\text { SIZE } \\
\text { AGE } \\
\text { RISK } \\
\text { RURAL }\end{array}$ & $\begin{array}{r}1.000 \\
0.228 \\
0.024 \\
-0.033 \\
-0.019 \\
-0.034 \\
0.022\end{array}$ & $\begin{array}{r}0.228 \\
1.000 \\
0.014 \\
-0.125 \\
-0.039 \\
0.034 \\
0.001\end{array}$ & $\begin{array}{r}0.024 \\
0.014 \\
1.000 \\
0.215 \\
0.012 \\
-0.220 \\
-0.018\end{array}$ & $\begin{array}{r}-0.033 \\
-0.125 \\
0.215 \\
1.000 \\
0.060 \\
-0.409 \\
0.078\end{array}$ & $\begin{array}{r}-0.019 \\
-0.039 \\
0.012 \\
0.060 \\
1.000 \\
-0.110 \\
-0.025\end{array}$ & $\begin{array}{r}-0.034 \\
0.034 \\
-0.220 \\
-0.409 \\
-0.110 \\
1.000 \\
-0.069\end{array}$ & $\begin{array}{r}0.022 \\
0.001 \\
-0.018 \\
0.078 \\
-0.025 \\
-0.069 \\
1.000\end{array}$ \\
\hline
\end{tabular}




\section{Journal of Financial and Quantitative Analysis}

TABLE A3

\section{Defining the Family Firm in Alternative Ways}

Table A3 estimates the baseline model in equation (1) of the main text under seven alternative definitions of a family firm. We use an ordered logit model where the dependent variable PARTICIPATION can take on four different values: 3 if the family has both the CEO and the chair, 2 if the family has only the CEO, 1 if the family has only the chair, and 0 if the family holds neither position. OWNERSHIP is the lagged ultimate equity fraction held by the firm's largest family by ownership. PERFORMANCE is operating earnings after taxes divided by total assets in real terms averaged over the past 3 years, while SIZE is the lagged natural log of real sales in millions of NOK as of year-end 2013. PERFORMANCE and SIZE are both winsorized at the $1 \%$ and $99 \%$ tails. AGE is the natural log of the number of years since the firm was founded, while RISK is the natural log of the ratio between the standard deviation of sales and the mean sales over the previous 3 years. RURAL is a dummy variable that is 1 if and only if the family firm is located outside Norway's five largest cities. The sample consists of all private Norwegian family firms with limited liability over the period 2001-2013. We exclude financials, utilities, and subsidiaries, and we require positive assets, sales, and employment. A family is a group of owning individuals in the firm who are related by blood or marriage up to the fourth degree of kinship. Regressions 1-5 define the sample based on the largest ultimate equity fraction of a family, while regressions 6 and 7 use only direct ownership and ignore family relationships. Every regression includes industry and year dummies. Standard errors are clustered at the firm level and reported in italics below the estimated coefficient. ${ }^{*}$ and ${ }^{* *}$ indicate $t$-values statistically different from 0 at the $5 \%$ and $1 \%$ levels, respectively.

Dependent Variable: PARTICIPATION

Definition of the Family Firm

\begin{tabular}{|c|c|c|c|c|c|c|c|}
\hline & & & & & & & \\
\hline OWNERSHIP & $\begin{array}{l}0.044^{\star *} \\
0.000\end{array}$ & $\begin{array}{l}0.044^{\star \star} \\
0.000\end{array}$ & $\begin{array}{l}0.045^{\star \star} \\
0.001\end{array}$ & $\begin{array}{l}0.028^{\star \star} \\
0.001\end{array}$ & $\begin{array}{l}0.026^{\star \star} \\
0.001\end{array}$ & $\begin{array}{l}0.046^{\star \star} \\
0.000\end{array}$ & $\begin{array}{l}0.046^{\star \star} \\
0.000\end{array}$ \\
\hline PERFORMANCE & $\begin{array}{l}0.412^{* *} \\
0.000\end{array}$ & $\begin{array}{l}0.415^{\star *} \\
0.000\end{array}$ & $\begin{array}{l}0.354^{* *} \\
0.031\end{array}$ & $\begin{array}{l}0.466^{\star \star} \\
0.037\end{array}$ & $\begin{array}{l}0.381^{\text {** }} 0.041\end{array}$ & $\begin{array}{l}0.347^{\star *} \\
0.000\end{array}$ & $\begin{array}{l}0.306^{\star \star} \\
0.000\end{array}$ \\
\hline SIZE & $\begin{array}{c}-0.127^{\star *} \\
0.000\end{array}$ & $\begin{array}{c}-0.129^{\star *} \\
0.000\end{array}$ & $\begin{array}{c}-0.101^{* *} \\
0.006\end{array}$ & $\begin{array}{c}-0.120^{\star \star} \\
0.008\end{array}$ & $\begin{array}{c}-0.100^{\star \star} \\
0.009\end{array}$ & $\begin{array}{c}-0.091^{\star *} \\
0.000\end{array}$ & $\begin{array}{c}-0.094^{\star \star} \\
0.000\end{array}$ \\
\hline AGE & $\begin{array}{l}0.008 \\
0.411\end{array}$ & $\begin{array}{l}0.008 \\
0.389\end{array}$ & $\begin{array}{l}0.012 \\
0.011\end{array}$ & $\begin{array}{c}-0.028^{\star} \\
0.013\end{array}$ & $\begin{array}{c}-0.052^{\star \star} \\
0.014\end{array}$ & $\begin{array}{l}0.002 \\
0.834\end{array}$ & $\begin{array}{l}0.010 \\
0.342\end{array}$ \\
\hline RISK & $\begin{array}{c}-0.035^{\star *} \\
0.000\end{array}$ & $\begin{array}{c}-0.036^{\star *} \\
0.000\end{array}$ & $\begin{array}{c}-0.025^{* *} \\
0.006\end{array}$ & $\begin{array}{c}-0.059^{\star \star} \\
0.007\end{array}$ & $\begin{array}{c}-0.064^{\star \star} \\
0.008\end{array}$ & $\begin{array}{c}-0.023^{* *} \\
0.000\end{array}$ & $\begin{array}{c}-0.022^{\star \star} \\
0.000\end{array}$ \\
\hline RURAL & $\begin{array}{r}-0.003 \\
0.813\end{array}$ & $\begin{array}{r}-0.002 \\
0.901\end{array}$ & $\begin{array}{r}-0.019 \\
0.017\end{array}$ & $\begin{array}{l}0.010 \\
0.021\end{array}$ & $\begin{array}{l}0.032 \\
0.024\end{array}$ & $\begin{array}{r}-0.015 \\
0.340\end{array}$ & $\begin{array}{r}-0.016 \\
0.297\end{array}$ \\
\hline $\begin{array}{l}\text { Pseudo- } R^{2} \\
N\end{array}$ & $\begin{array}{r}0.158 \\
506,651\end{array}$ & $\begin{array}{r}0.145 \\
496,082\end{array}$ & $\begin{array}{r}0.132 \\
442,935\end{array}$ & $\begin{array}{r}0.039 \\
364,916\end{array}$ & $\begin{array}{r}0.022 \\
322,294\end{array}$ & $\begin{array}{r}0.150 \\
467,757\end{array}$ & $\begin{array}{r}0.162 \\
491,692\end{array}$ \\
\hline
\end{tabular}


TABLE A4

\section{Alternative Measures of Participation Intensity}

Table A4 estimates the baseline model in equation (1) of the main text under seven alternative definitions of participation intensity. Models 1-3 compare the controlling family's most intensive governance participation (CEO \& chair) to less intensive participation (only CEO, only chair, and neither, respectively). The dependent variable equals 1 if the controlling family has both the CEO and the chair, while it is 0 if the controlling family has only the CEO, only the chair, and neither, respectively. Model 4 compares family firms where the CEO does versus does not come from the controlling family, while model 5 compares family firms with and without the same person in the controlling family holding both the CEO and chair positions. The dependent variable in model 6 is a dummy variable that equals 1 if the board consists entirely of family members. Model 7 compares family firms with different fractions of the board seats held by the controlling family. Models 1-6 are logit regressions, while model 7 is an OLS regression. OWNERSHIP is the lagged ultimate equity fraction held by the firm's largest family by ownership. PERFORMANCE is operating earnings after taxes divided by total assets in real terms averaged over the past 3 years, while SIZE is the lagged natural log of real sales in millions of NOK as of year-end 2013. PERFORMANCE and SIZE are both winsorized at the $1 \%$ and $99 \%$ tails. AGE is the natural log of the number of years since the firm was founded, while RISK is the natural log of the ratio between the standard deviation of sales and the mean sales over the previous 3 years. RURAL is a dummy variable that is 1 if and only if the family firm is located outside Norway's five largest cities. The sample consists of all private Norwegian family firms with limited liability over the period 2001-2013. We exclude financials, utilities, and subsidiaries, and we require positive assets, sales, and employment. A family is a group of owning individuals in the firm who are related by blood or marriage up to the fourth degree of kinship. A family firm is a firm in which the ultimate equity share of the largest family by ownership exceeds $50 \%$. All regressions include industry and year dummies. The standard errors are clustered at the firm level and reported in italics below the estimated coefficient. ${ }^{*}{ }^{* *}$, and ${ }^{* *}$ indicate $t$-values statistically different from 0 at the $10 \%, 5 \%$, and $1 \%$ levels, respectively.

\begin{tabular}{|c|c|c|c|c|c|c|c|}
\hline & 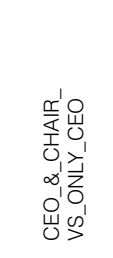 & 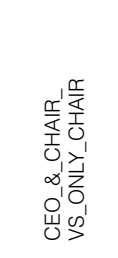 & 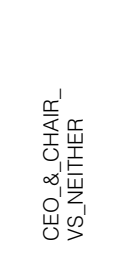 & $\begin{array}{l}0 \\
\bigcup_{1} \\
0^{\prime} \\
z_{1} \\
0^{\prime} \\
O_{1}^{\prime} \\
\mathcal{U}^{\prime}\end{array}$ & 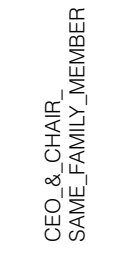 & 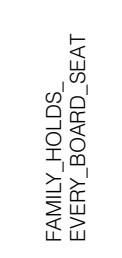 & 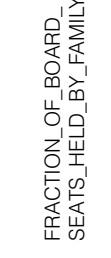 \\
\hline Independent Variable & 1 & 2 & 3 & 4 & 5 & 6 & 7 \\
\hline OWNERSHIP & $\begin{array}{l}0.043^{\text {*** }} \\
0.001\end{array}$ & $\begin{array}{l}0.018^{\star \star *} \\
0.001\end{array}$ & $\begin{array}{l}0.043^{\star \star \star} \\
0.001\end{array}$ & $\begin{array}{l}0.019^{\star \star \star *} \\
0.001\end{array}$ & $\begin{array}{l}0.025^{\star \star \star} \\
0.024\end{array}$ & $\begin{array}{l}0.060^{\star \star \star} \\
0.001\end{array}$ & $\begin{array}{l}0.007^{\star \star \star} \\
0.002\end{array}$ \\
\hline PERFORMANCE & $\begin{array}{l}0.816^{\text {*** }} \\
0.056\end{array}$ & $\begin{array}{l}0.221^{\star \star \star} \\
0.047\end{array}$ & $\begin{array}{l}0.976^{\star \star \star} \\
0.078\end{array}$ & $\begin{array}{l}0.266^{\star \star \star} \\
0.025\end{array}$ & $\begin{array}{l}0.659^{* \star *} \\
0.022\end{array}$ & $\begin{array}{l}0.725^{\star \star \star} \\
0.002\end{array}$ & $\begin{array}{l}0.061^{\star \star \star} \\
0.002\end{array}$ \\
\hline SIZE & $\begin{array}{l}-0.372^{\star * *} \\
0.015\end{array}$ & $\begin{array}{l}-0.022^{\star *} \\
0.010\end{array}$ & $\begin{array}{l}-0.232^{\star \star \star} \\
0.020\end{array}$ & $\begin{array}{l}-0.022^{\star \star \star} \\
0.004\end{array}$ & $\begin{array}{l}-0.252^{* * *} \\
0.003\end{array}$ & $\begin{array}{l}-0.338^{\star \star *} \\
0.004\end{array}$ & $\begin{array}{l}-0.022^{\star \star \star} \\
0.001\end{array}$ \\
\hline AGE & $\begin{array}{l}0.056^{* *} \\
0.023\end{array}$ & $\begin{array}{c}-0.028^{*} \\
0.016\end{array}$ & $\begin{array}{c}-0.078^{\star \star} \\
0.032\end{array}$ & $\begin{array}{l}-0.026^{\star \star \star} \\
0.007\end{array}$ & $\begin{array}{l}-0.050^{* * *} \\
0.006\end{array}$ & $\begin{array}{l}0.029^{* * *} \\
0.007\end{array}$ & $\begin{array}{l}0.005^{\star \star \star} \\
0.001\end{array}$ \\
\hline RISK & $\begin{array}{l}-0.079^{* \star *} \\
0.012\end{array}$ & $\begin{array}{l}-0.043^{\star \star \star} \\
0.010\end{array}$ & $\begin{array}{l}-0.067^{\star \star \star} \\
0.018\end{array}$ & $\begin{array}{l}-0.038^{\star \star \star} \\
0.005\end{array}$ & $\begin{array}{l}-0.012^{\star \star \star} \\
0.004\end{array}$ & $\begin{array}{l}-0.056^{\star \star \star} \\
0.005\end{array}$ & $\begin{array}{l}-0.006^{\star \star \star} \\
0.001\end{array}$ \\
\hline RURAL & 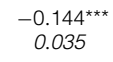 & $\begin{array}{l}0.068^{* *} \\
0.028\end{array}$ & $\begin{array}{r}-0.006 \\
0.048\end{array}$ & $\begin{array}{l}0.080^{\star \star *} \\
0.010\end{array}$ & $\begin{array}{l}-0.143^{\star * *} \\
0.008\end{array}$ & $\begin{array}{l}-0.111^{\star * *} \\
0.010\end{array}$ & $\begin{array}{l}-0.004^{\star \star \star} \\
0.001\end{array}$ \\
\hline $\begin{array}{l}\text { Pseudo- } R^{2} / \text { Adj. } R^{2} \\
N\end{array}$ & $\begin{array}{r}0.125 \\
315,222\end{array}$ & $\begin{array}{r}0.018 \\
331,927\end{array}$ & $\begin{array}{r}0.115 \\
298,999\end{array}$ & $\begin{array}{r}0.020 \\
364,916\end{array}$ & $\begin{array}{r}0.057 \\
337,272\end{array}$ & $\begin{array}{r}0.221 \\
363,782\end{array}$ & $\begin{array}{r}0.221 \\
363,782\end{array}$ \\
\hline
\end{tabular}




\section{References}

Adams, R. B.; B. E. Hermalin; and M. S. Weisbach. "The Role of Boards of Directors in Corporate Governance: A Conceptual Framework and Survey." Journal of Economic Literature, 48 (2010), 58-107.

Amit, R., and B. Villalonga. "Financial Performance of Family Firms." In The SAGE Handbook of Family Business, L. Melin, M. Nordqvist, and P. Sharma, eds. Thousand Oaks, CA: Sage (2014), 157-178.

Anderson, R. C., and D. R. Reeb. "Founding Family Ownership and Firm Performance: Evidence from the S\&P 500." Journal of Finance, 58 (2003), 1301-1328.

Bennedsen, M.; K. M. Nielsen; F. Perez-Gonzalez; and D. Wolfenzon. "Inside the Family Firm: The Role of Families in Succession Decisions and Performance." Quarterly Journal of Economics, 122 (2007), 647-691.

Berry, T. K.; J. M. Bizjak; M. L. Lemmon; and L. Naveen. "Organizational Complexity and CEO Labor Markets: Evidence from Diversified Firms.” Journal of Corporate Finance, 12 (2006), 797-817.

Berzins, J.; Ø. Bøhren; and B. Stacescu. "Shareholder Conflicts and Dividends." Review of Finance, 22 (2018), 1807-1840.

Bizjak, J. M.; J. A. Brickley; and J. Coles. "Stock-Based Incentive Compensation and Investment Behavior." Journal of Accounting and Economics, 16 (1993), 349-372.

Bøhren, Ø. Eierne, Styret og Ledelsen: Corporate Governance i Norge. Bergen, Norway: Fagbokforlaget (2011).

Brickley, J. A.; J. L. Coles; and G. Jarrell. "Leadership Structure: Separating the CEO and Chairman of the Board." Journal of Corporate Finance, 3 (1997), 189-220.

Brickley, J. A.; J. L. Coles; and R. L. Terry. "Outside Directors and the Adoption of Poison Pills." Journal of Financial Economics, 35 (1994), 371-390.

Cao, J.; D. Cumming; and X. Wang. "One-Child Policy and Family Firms in China." Journal of Corporate Finance, 33 (2015), 317-329.

Coles, J. L.; N. Daniel; and L. Naveen. "Boards: Does One Size Fit All?" Journal of Financial Economics, 87 (2008), 329-356.

Coles, J. L.; M. L. Lemmon; and F. Meschke. "Structural Models and Endogeneity in Corporate Finance: The Link between Managerial Ownership and Corporate Performance." Journal of Financial Economics, 103 (2012), 149-168.

Demsetz, H., and K. Lehn. "The Structure of Corporate Ownership: Causes and Consequences." Journal of Political Economy, 93 (1985), 1155-1177.

Gomes, A. "Going Public without Governance: Managerial Reputation Effects." Journal of Finance, 55 (2000), 615-646.

Greene, W. H., and D. A. Hensher. "Modeling Ordered Choices: A Primer and Recent Developments." Working Paper, New York University (2008).

Holtz-Eakin, D.; W. Newey; and H. S. Rosen. "Estimating Vector Autoregressions with Panel Data." Econometrica, 56 (1988), 1371-1395.

International Monetary Fund. "IMF Data Mapper, GDP Per Capita.” Paris, France: International Monetary Fund, http://www.imf.org/external/datamapper/PPPPC@WEO/THA (2018).

Jensen, M. C., and W. H. Meckling. "Theory of the Firm: Managerial Behavior, Agency Costs and Ownership Structure.” Journal of Financial Economics, 3 (1976), 305-360.

Johnson, S.; R. La Porta; F. Lopez-de-Silanes; and A. Shleifer. "Tunneling." American Economic Review Papers and Proceedings, 90 (2000), 22-27.

La Porta, R.; F. Lopez-de-Silanes; A. Shleifer; and R. W. Vishny. "Law and Finance." Journal of Political Economy, 106 (1998), 1113-1155.

La Porta, R.; F. Lopez-de-Silanes; A. Shleifer; and R. W. Vishny. "Investor Protection and Corporate Governance." Journal of Financial Economics, 58 (2000), 3-27.

Larcker, D. F., and T. O. Rusticus. "Endogeneity and Empirical Accounting Research." European Accounting Review, 16 (2007), 207-215.

Leland, H., and D. H. Pyle. "Informational Asymmetries, Financial Structure, and Financial Intermediation." Journal of Finance, 32 (1977), 371-387.

Liu, Q., and Z. Lu. "Corporate Governance and Earnings Management in the Chinese Listed Companies: A Tunneling Perspective.” Journal of Corporate Finance, 13 (2007), 881-906.

Love, I., and L. Zicchino. "Financial Development and Dynamic Investment Behavior: Evidence from Panel VAR." Quarterly Review of Economics and Finance, 46 (2006), 190-210.

Luo, X., and C. N. Chung. "Keeping It All in the Family: The Role of Pluralistic Relationships in Business Group Performance during Institutional Transition." Administrative Science Quarterly, 50 (2005), 404-439. 
Maury, B. "Family Ownership and Firm Performance: Empirical Evidence from Western European Corporations." Journal of Corporate Finance, 12 (2006), 321-341.

Morck, R.; A. Shleifer; and R. W. Vishny. "Management Ownership and Market Valuation: An Empirical Analysis." Journal of Financial Economics, 20 (1988), 293-315.

Naveen, L. "Organizational Complexity and Succession Planning." Journal of Financial and Quantitative Analysis, 41 (2006), 661-683.

Nicholson, N. "Evolutionary Psychology, Corporate Culture and Family Business." Academy of Management Perspectives, 22 (2008), 73-84.

O’Boyle, E. H. Jr.; J. M. Pollack; and M. W. Rutherford. "Exploring the Relation between Family Involvement and Firms' Financial Performance: A Meta-Analysis of Main and Moderator Effects." Journal of Business Venturing, 27 (2012), 1-18.

OECD. "Education at a Glance 2016: OECD Indicators." Paris, France: OECD Publishing, http:// download.ei-ie.org/Docs/WebDepot/EaG2016_EN.pdf (2016).

Pollack, R. A. "A Transaction Cost Approach to Families and Households." Journal of Economic Literature, 23 (1985), 581-608.

Roberts, M. R., and T. M. Whited. "Endogeneity in Empirical Corporate Finance." In Handbook of the Economics of Finance, Vol. 2, G. Constantinides, M. Harris, and R. Stulz, eds. Amsterdam, The Netherlands: Elsevier (2013), 493-572.

Shleifer, A., and R. W. Vishny. "Large Shareholders and Corporate Control." Journal of Political Economy, 94 (1986), 461-488.

Spamann, H. "The Anti-Director Rights Index Revisited.” Review of Financial Studies, 23 (2010), 467-486.

Sraer, D., and D. Thesmar. "Performance and Behavior of Family Firms: Evidence from the French Stock Market." Journal of the European Economic Association, 5 (2007), 709-751.

Tirole, J. “Corporate Governance.” Econometrica, 69 (2001), 1-35.

Tönnies, F. Gemeinschaft und Gesellschaft. Leipzig, Germany: Fues’s Verlag (1887).

Villalonga, B., and R. Amit. "How Do Family Ownership, Control and Management Affect Firm Value?" Journal of Financial Economics, 80 (2006), 385-417.

Young, M. N.; M. W. Peng; D. Ahlstrom; G. D. Bruton; and Y. Jiang. "Corporate Governance in Emerging Economies: A Review of the Principal-Principal Perspective." Journal of Management Studies, 45 (2008), 196-220. 